\title{
Synthesis and Complexation Studies of Optically Active Aza- and Diazacrown Ethers Containing a Pyrene Fluorophore Unit
}

\author{
Dávid Pál1', Martin Gede, Ildikó Móczár, Péter Baranyai², Péter Bagi', Péter Huszthy ${ }^{1 *}$ \\ 1 Department of Organic Chemistry and Technology, Faculty of Chemical Technology and Biotechnology, Budapest University of \\ Technology and Economics, P.O.B. 91, H-1521 Budapest, Hungary \\ 2 Department of Applied and Nolinear Optics, Institute of Solid State Physics and Optics, Wigner Research Center for Physics, \\ Hungarian Academy of Sciences, P.O.B. 49, H-1525 Budapest, Hungary \\ *Corresponding author, e-mail: huszthy@mail.bme.hu
}

Received: 28 May 2019, Accepted: 26 August 2019, Published online: 21 October 2019

\begin{abstract}
Novel enantiopure azacrown $[(R, R)-\mathbf{1}$ and $(S, S)-\mathbf{1}]$ and diazacrown $[(R, R)-\mathbf{2}-(R, R)-\mathbf{4}$ and $(S, S)-\mathbf{2}-(S, S)-\mathbf{4}]$ ethers containing a pyrene fluorophore unit and two phenyl groups at their chiral centers were obtained in multistep syntheses. The action of these chemosensors is based on the photoinduced electron transfer (PET) process, thus they show fluorescence enhancement in the presence of protonated primary amines and amino acid esters. Their recognition abilities toward the enantiomers of 1-phenylethylamine hydrogen perchlorate (PEA), 1-(1-naphthyl) ethylamine hydrogen perchlorate (NEA), phenylglycine methyl ester hydrogen perchlorate (PGME), and phenylalanine methyl ester hydrogen perchlorate (PAME) were examined in acetonitrile using fluorescence spectroscopy.
\end{abstract}

Keywords

molecular recognition, fluorescence, PET sensor, azacrown ether, chiral crown ether

\section{Introduction}

Host-guest molecular recognition of organic ammonium ions is important in a variety of processes such as the interaction of molecules bearing ammonium ions with protein receptors [1]. Our current research in molecular recognition focuses on the interactions of fluorescent optically active crown ethers with protonated chiral primary amines and amino acid esters. Discrimination of the enantiomers of biologically active primary amines, amino acids, and amino alcohols including neurotransmitters, vital $\alpha$-amino acids, and active pharmaceutical ingredients is also of great importance because of the potentially diverse physiological effects of such species [2]. The sensing based on fluorescence is attractive due to the selectivity, high sensitivity and quick response time of fluorescence spectroscopy [3]. Great efforts have been made on the design, synthesis, and use of chiral fluorescent chemosensors [4-19]. The first use of photophysical techniques for elucidation of chiral recognition by crown ethers was reported in 1980 [20]. Since then, other optically active crown ethers containing different fluorophore units have been synthesized to this purpose, and their enantiomeric discrimination abilities toward the enantiomers of primary amines, amino acids, amino alcohols, and their derivatives were investigated [21, 22]. Some of them were tested with both protonated primary amines and amino acid esters [21-26].

Certain free fluorescent sensor molecules have poor fluorescence due to an efficient quenching process (photoinduced electron transfer, PET) in the excited state. Upon complexation with different cationic guests they show fluorescence enhancement, by this providing a very sensitive response to such analytes [27-37]. Using PET type fluorescent chemosensors is advantageous, because their behavior can be predicted; therefore, for example, guest-induced 'off-on' fluorescence is designable [27, 33]. These sensor molecules have a 'fluorophore-spacer-receptor' structure, in which distinct components perform each one of the necessary functions. The fluorophore unit is the site of excitation and emission, and the receptor unit is responsible for guest complexation. The spacer, which is often a short alkylene group, holds the fluorophore and receptor close to, but separate from, each other. Several host molecules 
possessing the modular structure referred above, among them crown ethers too, have been synthesized, and their selectivities for different metal ions or organic cations have been studied [27-37]. Some reported aza- and azathiacrown ethers contain a pyrene fluorophore unit attached by a methylene spacer to the nitrogen atom of the crown ether, which enables PET type fluorescence response in the presence of inorganic cations [38-42]. Optically active azacrown etherbased PET chemosensors having a modular structure and a binaphthyl chiral unit [43] or alkyl groups at their chiral centers [44] were also synthesized. Their enantiomeric recognition abilities toward chiral ammonium salts [43, 44] and potassium mandelate [44] were examined.

Considering these results, we designed and synthesized novel enantiopure azacrown $[(R, R)-\mathbf{1}$ and $(S, S)-\mathbf{1}]$ and diazacrown $[(R, R)-\mathbf{2}-(R, R)-\mathbf{4}$ and $(S, S)-2-(S, S)-4]$ ethers (Fig. 1) having phenyl groups at their stereogenic centers and a pyrene fluorescent signaling unit attached through a methylene bridge to the nitrogen atom of the macrocycles. Studies on the molecular recognition abilities of these fluorescent sensor molecules toward the enantiomers of protonated chiral primary amines and amino acid esters were performed in acetonitrile using fluorescence spectroscopy.

\section{Results and discussion}

\subsection{Synthesis}

The synthesis of new azacrown ether derivatives $(R, R)-\mathbf{1}$ and $(S, S)-\mathbf{1}$ (Fig. 1) was carried out as outlined in Scheme 1. Pyren-1-ylmethanamine (5) [45] was heated with $(R)$-phenyloxirane and $(S)$-phenyloxirane in methanol in sealed tubes to give enantiopure aminodiols $(R, R)-\mathbf{6}$ and $(S, S)-\mathbf{6}$, respectively. Azacrown ether derivatives $(R, R)-\mathbf{1}$ and $(S, S)$-1 were prepared by a macrocyclization reaction starting from aminodiol $(R, R)-\mathbf{6}$ or $(S, S)$-6 and tetraethylene glycol ditosylate (7) [46] in THF using sodium hydride as a strong base.

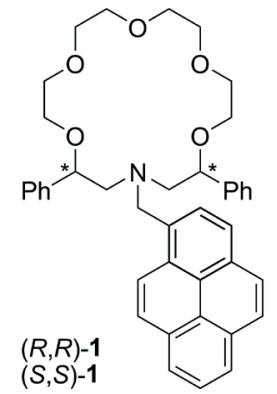

$(R, R)-2,(S, S)-2: \mathrm{R}=\mathrm{H}$ $(R, R)-3,(S, S)-3: \mathrm{R}=\mathrm{CHO}$ $(R, R)-4,(S, S)-4: \mathrm{R}=\mathrm{Me}$

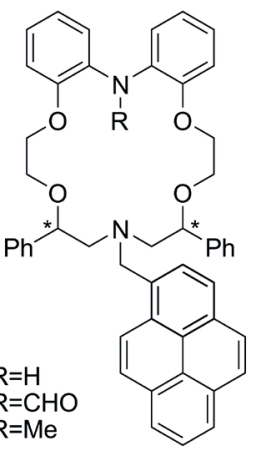

Fig. 1 Schematics of enantiopure aza- and diazacrown ethers containing a pyrene fluorophore unit

The preparation of diazacrown ethers $(R, R)-\mathbf{2}-(R, R)-\mathbf{4}$ and $(S, S)-2-(S, S)-4$ is shown in Scheme 2. Bis(2methoxyphenyl)amine (8) [47] was treated with methyl iodide in THF in the presence of sodium hydride to obtain $N$-methylated amine 9. Diphenol 10 has already been synthesized, but not fully characterized [48, 49]. For the synthesis of diphenol $\mathbf{1 0}$, selective $O$-demethylation of amine 9 was carried out with anhydrous aluminium chloride in chlorobenzene adopting the procedure [50] described for the synthesis of $N$-formyl analogue 11. Diphenol derivatives $\mathbf{1 1}$ and $\mathbf{1 0}$ were reacted with benzyl protected ethylene glycol tosylate (12) [51] in acetonitrile using potassium carbonate to furnish formamide derivative 13 and tertiary amine 14, respectively. Diols 15 and 16 were prepared from $O$-benzyl protected derivatives 13 and 14 by catalytic hydrogenolysis in methanol. Tosylation of diols $\mathbf{1 5}$ and $\mathbf{1 6}$ in dichloromethane gave ditosylates $\mathbf{1 7}$ and 18 in very good yields. Formamide derivative 15 was reacted in the presence of triethylamine as a base, while $N$-methyl derivative 16 was tosylated using aqueous potassium hydroxide. The macrocyclization reactions of ditosylates 17 and 18 with aminodiol $(R, R)-6$ or $(S, S)$-6 were carried out in DMF in the presence of sodium hydride. The reactions of $\mathbf{1 7}$ rendered $(R, R)-\mathbf{2}$ and $(S, S)-\mathbf{2}$ due to deformylation. Sensor molecules $(R, R)-\mathbf{4}$ and $(S, S)$-4 were

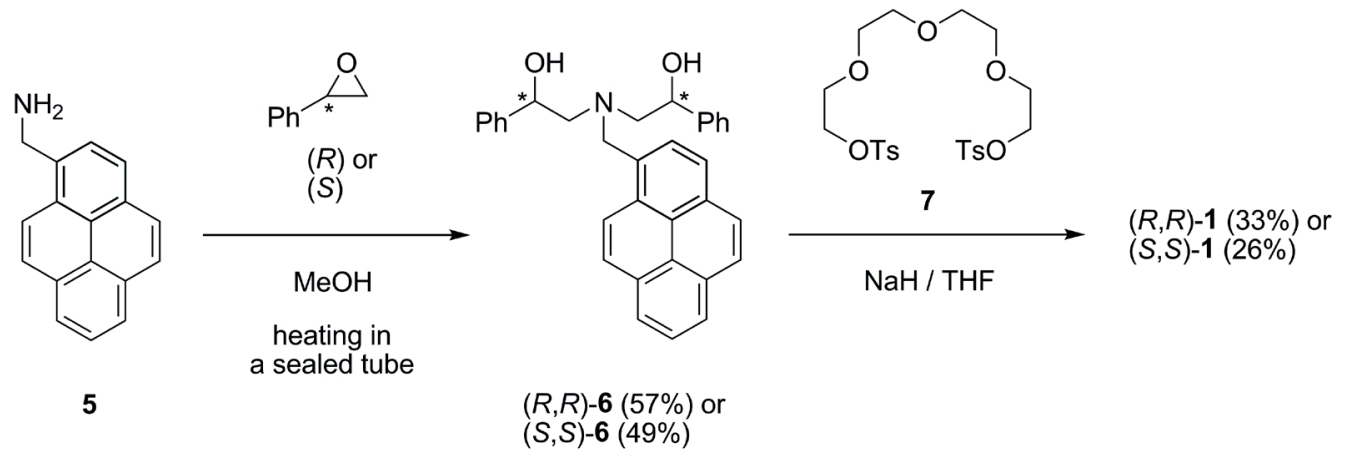

Scheme 1 Synthesis of sensor molecules $(R, R)-\mathbf{1}$ and $(S, S)-\mathbf{1}$ 


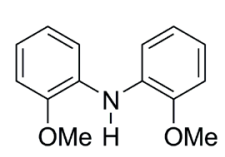

8

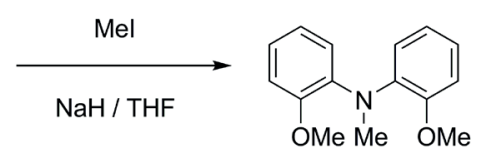

$9(95 \%)$

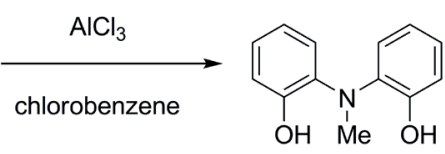

$10(76 \%)$<smiles>[R]N(c1ccccc1O)c1ccccc1O</smiles>
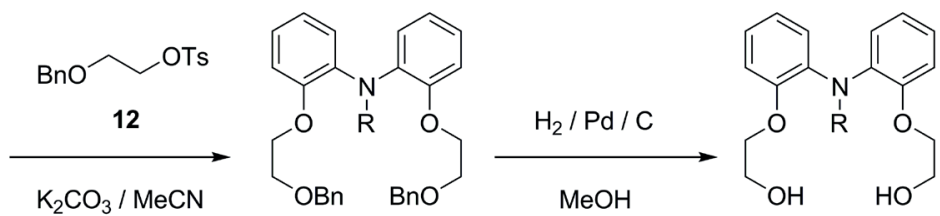
11: $\mathrm{R}=\mathrm{CHO}$ or
10: $\mathrm{R}=\mathrm{Me}$ 13: $\mathrm{R}=\mathrm{CHO}(77 \%)$ or 14: $\mathrm{R}=\mathrm{Me}(78 \%)$

15: $\mathrm{R}=\mathrm{CHO}(98 \%)$ or 16: $\mathrm{R}=\mathrm{Me}(100 \%)$

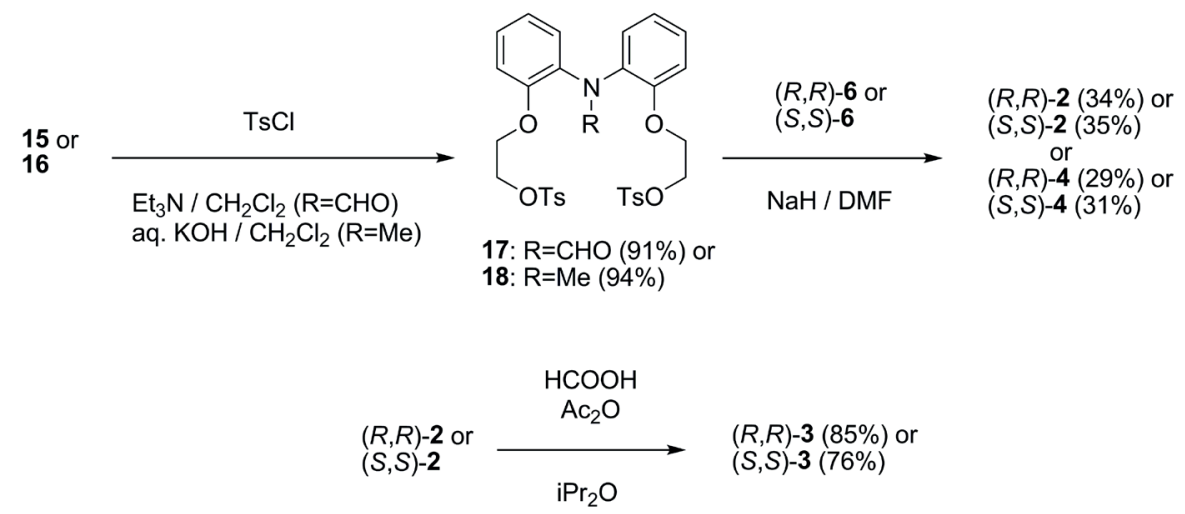

Scheme 2 Synthesis of sensor molecules $(R, R)-\mathbf{2}-(R, R)-\mathbf{4}$ and $(S, S)-\mathbf{2}-(S, S)-\mathbf{4}$

prepared from 18. Formylation of $(R, R)-\mathbf{2}$ and $(S, S)$-2 using a mixture of formic acid and acetic anhydride gave $(R, R)-\mathbf{3}$ and $(S, S)-\mathbf{3}$ successfully.

We worked out another route for the synthesis of diazacrown ether $(S, S)$-4 through novel enantiopure precursors (Scheme 3), which can be useful for the preparation of enantioselective fluorescent sensor molecules. Methoxymethyl (MOM)-protected ethylene glycol 19 [52] was tosylated to obtain tosylate 20. Reaction of the latter with enantiopure aminodiol $(R, R)-\mathbf{6}$ or $(S, S)$-6 was carried out in a mixture of THF and DMF using sodium hydride as a base to give MOM ethers $(R, R)-\mathbf{2 1}$ and $(S, S)-\mathbf{2 1}$. The removal of the MOM protecting groups of $(R, R)-\mathbf{2 1}$ and $(S, S)$-21 by aqueous hydrochloric acid in THF furnished diols $(R, R)-\mathbf{2 2}$ and $(S, S)$-22, which were transformed into their ditosylate derivatives $(R, R)$-23 and $(S, S)$-23. O-Alkylation of diphenol derivative $\mathbf{1 0}$ with $(S, S)-\mathbf{2 3}$ in acetonitrile using potassium carbonate yielded macrocycle $(S, S)-\mathbf{4}$.

\subsection{Complexation studies}

Azacrown ethers $(R, R)-\mathbf{1}$ and $(S, S)-\mathbf{1}$ and diazacrown ethers $(R, R)-\mathbf{2}-(R, R)-\mathbf{4}$ and $(S, S)-\mathbf{2}-(S, S)-\mathbf{4}$ (Fig. 1) have a modular (fluorophore-methylene spacer-receptor) structure, thereby
PET type fluorescence response was expected upon complex formation with various chiral primary ammonium salts. It means that the free sensor molecule has strongly reduced fluorescence due to a quenching process (PET) in the excited state directed from the donor nitrogen atom of the crown ether to the acceptor fluorophore unit. Conversely, coordination of a cation decreases the electron donating ability of the nitrogen atom, which induces a significant fluorescence enhancement without spectral shifts.

Crown ethers $(R, R)-\mathbf{1}-(R, R)-\mathbf{4}$ and $(S, S)-\mathbf{1}-(S, S)-\mathbf{4}$ have phenyl substituents at their chiral centers. Besides the other aromatic moieties in the receptors, these phenyl substituents can also participate in $\pi-\pi$ interactions with the aromatic units and carbonyl groups of the ammonium cation guests or lone pair $-\pi$ interactions with the carbonyl groups of amino acid esters [53, 54].

The recognition abilities of these ligands toward the enantiomers of 1-phenylethylamine hydrogen perchlorate (PEA), 1-(1-naphthyl)ethylamine hydrogen perchlorate (NEA), phenylglycine methyl ester hydrogen perchlorate (PGME), and phenylalanine methyl ester hydrogen perchlorate (PAME) (Fig. 2) were studied in acetonitrile by $\mathrm{UV}-\mathrm{vis}$ and fluorescence spectroscopies. 


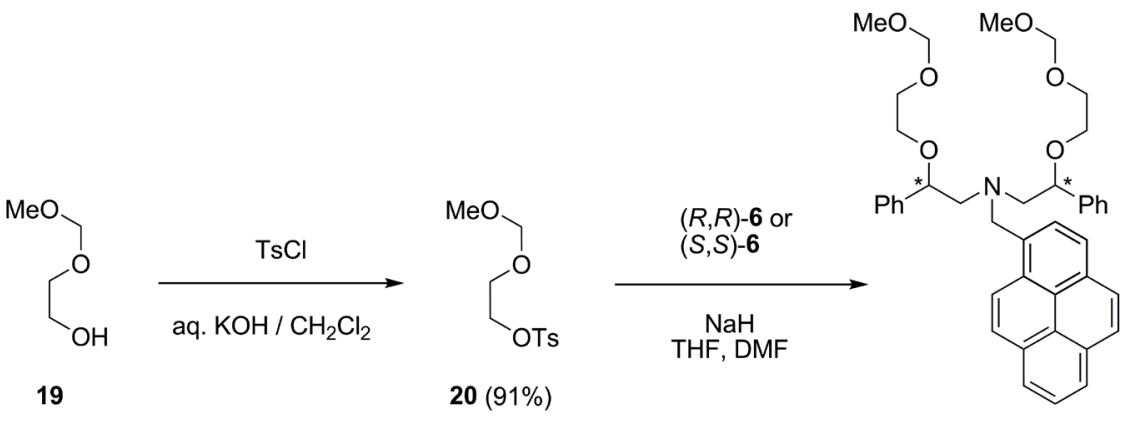

$(R, R)-21(67 \%)$ or
$(S, S)-21(70 \%)$

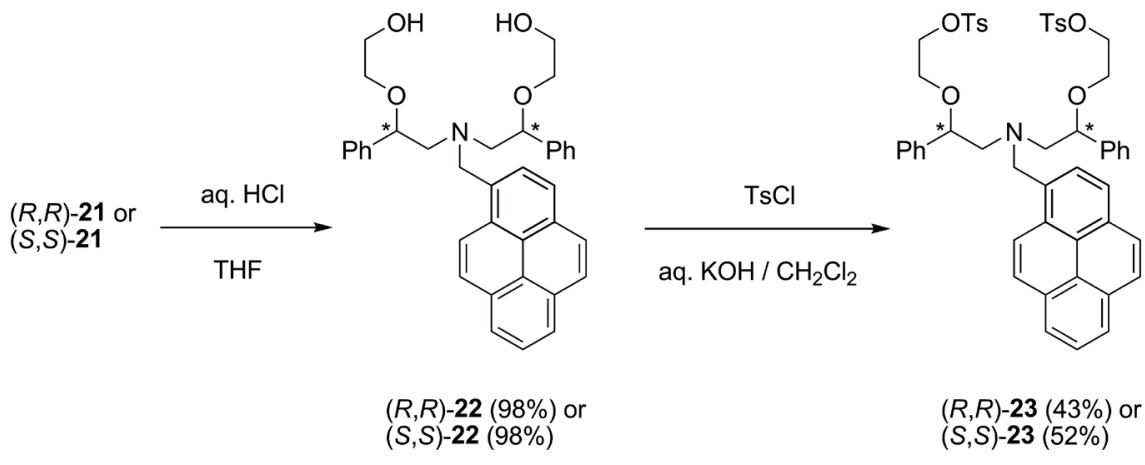

$(S, S)-23$

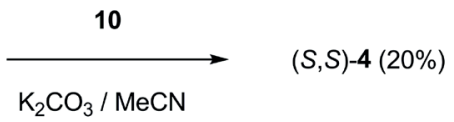

Scheme 3 Synthesis of enantiopure compounds containing a pyrene fluorophore

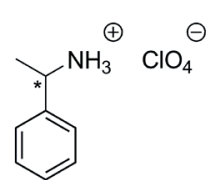

PEA

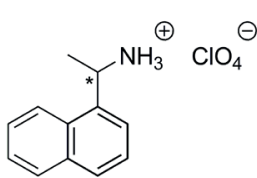

NEA

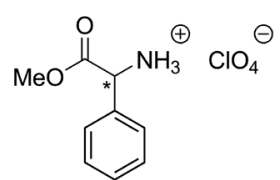

PGME

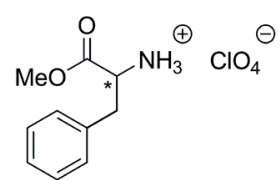

PAME

Fig. 2 Schematics of chiral primary ammonium salts used in the enantiomeric recognition studies

The absorption spectra of azacrown ethers $(R, R)-\mathbf{1}$ and $(S, S)$-1 showed very small changes upon addition of the chiral primary ammonium salts. During the titrations of diazacrown ethers $(R, R)-\mathbf{2}-(R, R)-\mathbf{4}$ and $(S, S)-\mathbf{2}-(S, S)-\mathbf{4}$ with these chiral guests, small spectral changes could be observed (Fig. 3).

However, the addition of PEA, NEA, PGME, and PAME to sensor molecules $(R, R)-\mathbf{1}-(R, R)-\mathbf{4}$ and $(S, S)-\mathbf{1}-(S, S)-\mathbf{4}$ resulted in large fluorescence enhancement (Fig. 4). In all cases, restoration of the pyrene fluorescence with emission bands at 378, 397, and $417 \mathrm{~nm}$ could be observed, because complexation of the chiral ammonium guests inhibited the PET quenching directed from the (trialkylamine type) nitrogen to the pyrene unit. Moreover, sensor molecules
$(R, R)-\mathbf{2},(S, S) \mathbf{- 2},(R, R)-\mathbf{4}$, and $(S, S)-\mathbf{4}$ showed decreases in their broad emission band above $450 \mathrm{~nm}$ upon complexation (Figs. 4B, D). This band, which was much more pronounced in the cases of ligands $(R, R)-\mathbf{2}$ and $(S, S)-\mathbf{2}$, can be attributed to the emission of an intramolecular exciplex formed by the pyrene-diphenylamine interaction.

All the fluorescence spectral changes were evaluated using global nonlinear regression analysis. The titration series of spectra could be fitted satisfactorily for 1:1 complex formation, and the stability constants (Table 1) as well as the degrees of enantiomeric differentiation (Table 2) were calculated.

The results in Table 1 show that macrocycles $(R, R)$-1$(R, R)-\mathbf{4}$ and $(S, S)-\mathbf{1}-(S, S)-\mathbf{4}$ form thermodynamically 

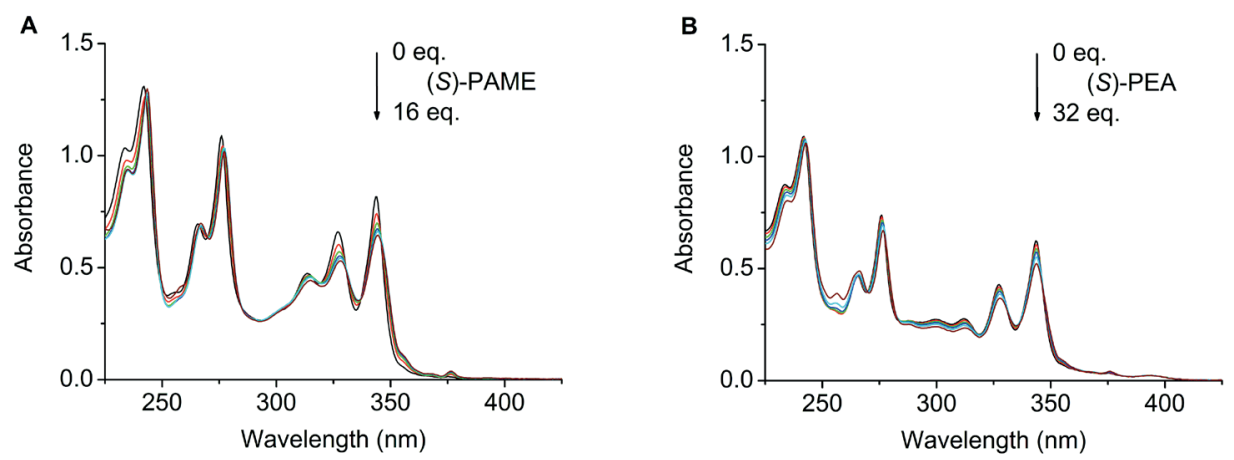

Fig. 3 Series of absorption spectra upon titration of $(S, S)$-2 $(20 \mu \mathrm{M})$ with $(S)$-PAME $(0,0.5,1,2,4,16$ equiv. $)(\mathbf{A}),(R, R)-4(20 \mu \mathrm{M})$ with $(S)$-PEA $(0,1,4,8,16,32$ equiv.) (B) in MeCN
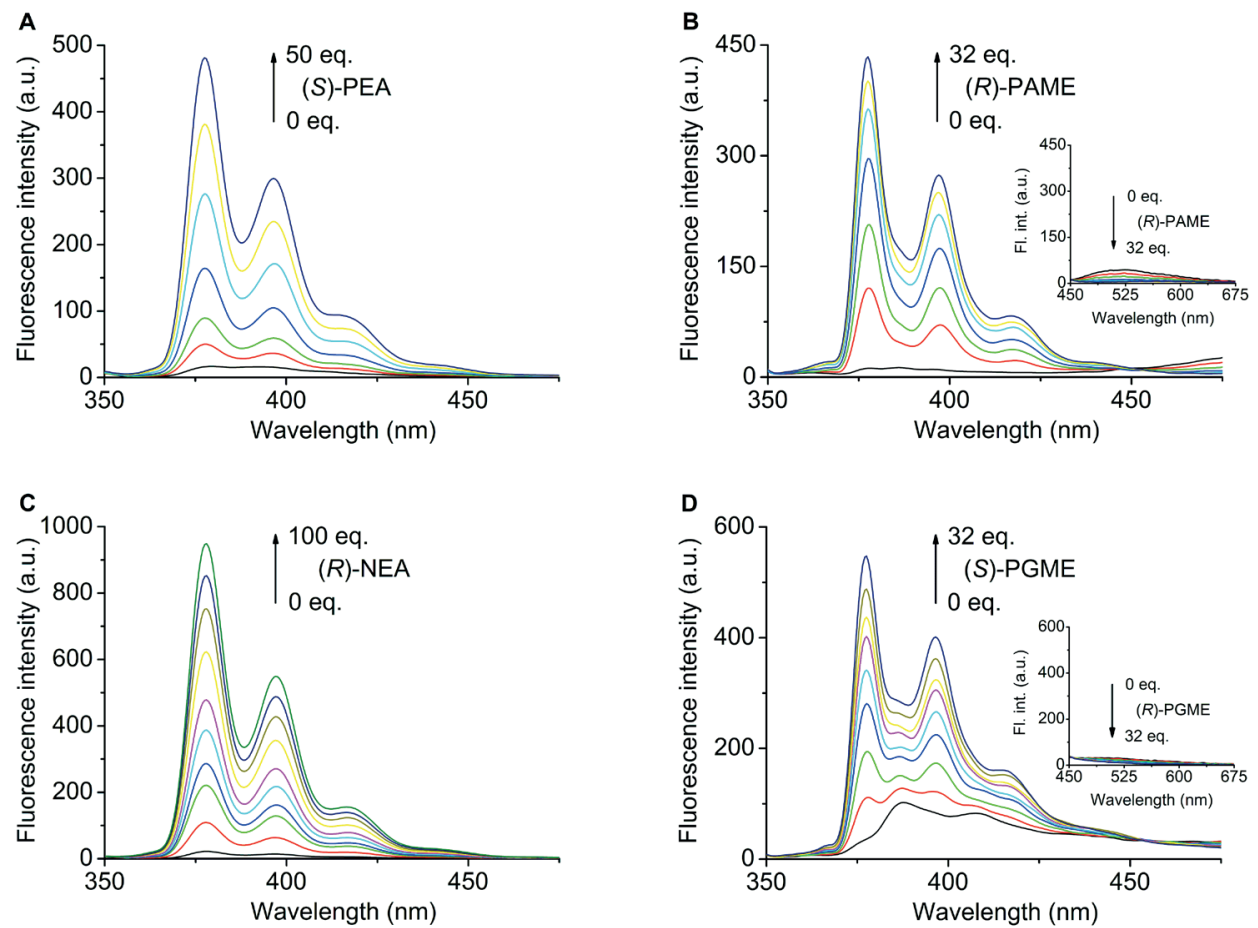

Fig. 4 Series of fluorescence emission spectra upon titration of $(S, S)-1(20 \mu \mathrm{M})$ with $(S)$-PEA $(0,0.1,0.4,1,4,8,50$ equiv. $)(\mathbf{A}),(S, S)-2(20 \mu \mathrm{M})$ with $(R)$-PAME $(0,0.25,0.5,1,2,7,32$ equiv. $)(\mathbf{B}),(S, S)-\mathbf{3}(20 \mu \mathrm{M})$ with $(R)$-NEA $(0,0.1,0.5,1,1.5,3,8,13,33,100$ equiv. $)(\mathbf{C})$, and $(S, S)-4(20 \mu \mathrm{M})$ with (S)-PGME $\left(0,0.25,0.5,0.75,1,1.5,2,7,32\right.$ equiv.) (D) in $\mathrm{MeCN}, \lambda_{\text {ex }}=344 \mathrm{~nm}$

stable complexes with chiral primary ammonium cations. The strongest binding of the enantiomers of PEA was observed in the case of azacrown ethers $(R, R)-\mathbf{1}$ and $(S, S)$-1 having a more flexible macroring. All the macrocycles formed more stable complexes with NEA than PEA. This can be explained by the presence of the extended aromatic system in the chiral ammonium salt resulting in larger $\pi-\pi$ interaction between the host and guest. It can be seen that the stabilities of PGME and PAME complexes are higher than those of PEA and NEA complexes. Diazacrown ethers $(R, R)-\mathbf{3}$ and $(S, S)$-3 formed significantly more stable complexes with protonated amino acid esters (PGME and PAME) than with protonated primary amines (PEA and NEA), which make them suitable for selective sensing the former type species (Fig. 5). It can be mentioned that other reported fluorescent optically active crown ethers, which were tested with these two types of guests, did not show such extent of difference in their binding affinities [21-26].

Dibenzo-diazacrown ethers $(R, R)-\mathbf{2}-(R, R)-\mathbf{4}$ and $(S, S)-2-(S, S)-\mathbf{4}$ have a more rigid system compared to azacrown ethers $(R, R)-\mathbf{1}$ and $(S, S)$-1; therefore, the observation of their enantiomeric discrimination ability toward the enantiomers of the strongly bound primary ammonium 
Table 1 Stability constants for complexes of $(R, R)-\mathbf{1}-(R, R)-\mathbf{4}$ and $(S, S)-\mathbf{1}-(S, S)-\mathbf{4}$ with the enantiomers of chiral primary ammonium salts in MeCN

\begin{tabular}{lcccccccc}
\hline & & & \multicolumn{3}{c}{$\log K$} \\
& $(R, R)-\mathbf{1}$ & $(S, S)-\mathbf{1}$ & $(R, R)-\mathbf{2}$ & $(S, S)-\mathbf{2}$ & $(R, R)-\mathbf{3}$ & $(S, S)-\mathbf{3}$ & $(R, R)-\mathbf{4}$ & $(S, S)-\mathbf{4}$ \\
\hline$(R)$-PEA & $4.86 \pm 0.04$ & $4.80 \pm 0.03$ & $3.10 \pm 0.05$ & $3.12 \pm 0.06$ & $3.83 \pm 0.05$ & $3.80 \pm 0.05$ & $4.07 \pm 0.06$ & $4.09 \pm 0.04$ \\
$(S)$-PEA & $4.90 \pm 0.04$ & $4.80 \pm 0.04$ & $3.18 \pm 0.05$ & $3.13 \pm 0.07$ & $3.79 \pm 0.05$ & $3.82 \pm 0.05$ & $4.12 \pm 0.05$ & $4.10 \pm 0.03$ \\
$(R)$-NEA & $4.93 \pm 0.05$ & $5.07 \pm 0.03$ & $3.37 \pm 0.06$ & $3.28 \pm 0.07$ & $4.01 \pm 0.04$ & $4.05 \pm 0.04$ & $4.93 \pm 0.05$ & $4.73 \pm 0.04$ \\
$(S)$-NEA & $5.01 \pm 0.05$ & $5.09 \pm 0.04$ & $3.42 \pm 0.06$ & $3.36 \pm 0.06$ & $4.08 \pm 0.04$ & $4.09 \pm 0.04$ & $4.85 \pm 0.05$ & $4.74 \pm 0.04$ \\
$(R)$-PGME & $6.21 \pm 0.16$ & $6.05 \pm 0.18$ & $4.90 \pm 0.07$ & $4.94 \pm 0.11$ & $6.48 \pm 0.12$ & $6.48 \pm 0.10$ & $5.10 \pm 0.04$ & $5.05 \pm 0.03$ \\
$(S)$-PGME & $6.14 \pm 0.18$ & $6.17 \pm 0.17$ & $4.95 \pm 0.09$ & $4.95 \pm 0.08$ & $6.43 \pm 0.12$ & $6.46 \pm 0.10$ & $5.03 \pm 0.04$ & $5.02 \pm 0.03$ \\
$(R)$-PAME & $6.25 \pm 0.11$ & $6.34 \pm 0.13$ & $4.75 \pm 0.06$ & $4.91 \pm 0.08$ & $6.26 \pm 0.10$ & $6.41 \pm 0.08$ & $5.05 \pm 0.04$ & $5.03 \pm 0.04$ \\
$(S)$-PAME & $6.27 \pm 0.10$ & $6.28 \pm 0.14$ & $4.86 \pm 0.07$ & $4.80 \pm 0.08$ & $6.25 \pm 0.10$ & $6.51 \pm 0.07$ & $5.11 \pm 0.02$ & $4.98 \pm 0.04$ \\
\hline
\end{tabular}

Table 2 Degrees of enantiomeric discrimination of $(R, R)-\mathbf{1}-(R, R)-\mathbf{4}$ and $(S, S)-\mathbf{1}-(S, S)-\mathbf{4}$ toward the enantiomers of chiral primary ammonium salts in $\mathrm{MeCN}$

\begin{tabular}{|c|c|c|c|c|c|c|c|c|}
\hline & \multicolumn{8}{|c|}{$\Delta \log K^{a}$} \\
\hline & $(R, R)-\mathbf{1}$ & $(S, S)-\mathbf{1}$ & $(R, R)-2$ & $(S, S)-\mathbf{2}$ & $(R, R)-\mathbf{3}$ & $(S, S)-\mathbf{3}$ & $(R, R)-4$ & $(S, S)-4$ \\
\hline $\begin{array}{l}(R)-\mathrm{PEA} \\
(S)-\mathrm{PEA}\end{array}$ & -0.04 & 0.00 & -0.08 & -0.01 & 0.04 & -0.02 & -0.05 & -0.01 \\
\hline $\begin{array}{l}(R) \text {-NEA } \\
(S) \text {-NEA }\end{array}$ & -0.08 & -0.02 & -0.05 & -0.08 & -0.07 & -0.04 & 0.08 & -0.01 \\
\hline $\begin{array}{l}(R)-\mathrm{PGME} \\
(S) \text {-PGME }\end{array}$ & 0.07 & -0.12 & -0.05 & -0.01 & 0.05 & 0.02 & 0.07 & 0.03 \\
\hline $\begin{array}{l}(R) \text {-PAME } \\
(S) \text {-PAME }\end{array}$ & -0.02 & 0.06 & -0.11 & 0.11 & 0.01 & -0.10 & -0.06 & 0.05 \\
\hline
\end{tabular}

${ }^{\mathrm{a}} \Delta \log K=\log K_{(R)}-\log K_{(S)}$

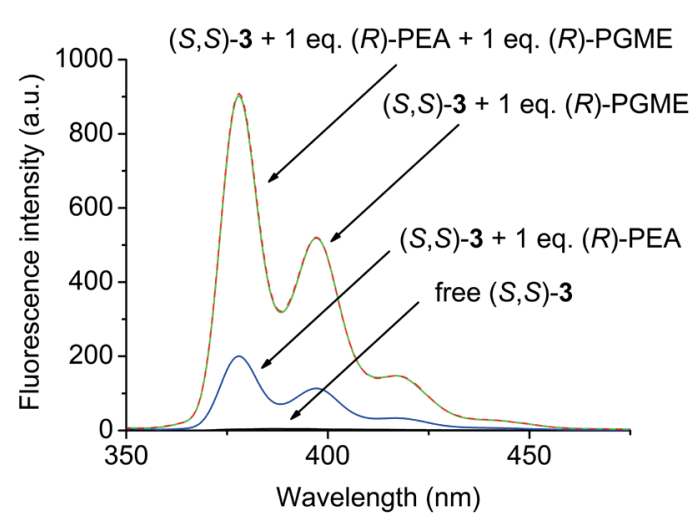

Fig. 5 Fluorescence emission spectra of free $(S, S)-\mathbf{3}(20 \mu \mathrm{M})$, with 1 equiv. of $(R)$-PEA, with 1 equiv. of $(R)$-PGME, and with 1 equiv. of $(R)$-PEA and 1 equiv. of $(R)$-PGME together in $\mathrm{MeCN}, \lambda_{\mathrm{ex}}=344 \mathrm{~nm}$

salts was expected. Unfortunately, the sensor molecules revealed practically no enantiomeric recognition ability as the data in Table 2 show.

\section{Conclusion}

The synthesis and characterization of novel enantiopure fluorescent azacrown $[(R, R)-\mathbf{1}$ and $(S, S)-\mathbf{1}]$ and diazacrown $[(R, R)-\mathbf{2}-(R, R)-\mathbf{4}$ and $(S, S)-\mathbf{2}-(S, S)-\mathbf{4}]$ ethers, and their broadly applicable precursors have been performed. The complex formation of the eight chiral ligands with the enantiomers of PEA, NEA, PGME, and PAME was studied by fluorescence spectroscopy using acetonitrile as a solvent. The sensor molecules exhibited PET type fluorescence response in the presence of these primary ammonium salts as expected. Complexation of the chiral guests was accompanied with large fluorescence enhancement in all cases; however, the macrocycles showed no enantiomeric recognition ability. Diazacrown ethers $(R, R)$-3 and $(S, S)$-3 formed significantly more stable complexes with protonated amino acid esters (PGME and PAME) than with protonated primary amines (PEA and NEA), thus these ligands can be good candidates for selective sensing of guests of the former type.

\section{Experimental}

\subsection{General}

All reagents were purchased from Sigma-Aldrich Corporation unless otherwise noted. Compounds 7 [46], 8 [47], 11 [50], and 12 [51] were prepared as reported in the respective literature. All reactions were monitored 
by TLC and visualized by UV lamp (254 nm). Silica gel $60 \mathrm{~F}_{254}$ (Merck) and aluminium oxide $60 \mathrm{~F}_{254}$ neutral type E (Merck) plates were used for TLC. Silica gel $60 \mathrm{PF}_{254}$ (Merck) and aluminium oxide $\mathrm{F}_{254}$ type $\mathrm{E}$ (Merck) plates were used for preparative TLC. Silica gel 60 (70-230 mesh, Merck) and aluminium oxide (neutral, activated, Brockman I) were used for column chromatography. Ratios of solvents for the eluents are given in volumes $(\mathrm{mL} / \mathrm{mL})$. Solvents were dried and purified according to well established methods [55]. Evaporations were carried out under reduced pressure.

Melting points were taken on a Boetius micro-melting point apparatus and are uncorrected. Enantiomeric excess (ee) values were determined by chiral HPLC systems. Chiral separation of $(R, R)-\mathbf{1}$ and $(S, S)-\mathbf{1}$ enantiomers was carried out on an Agilent 1100 liquid chromatography system. Chromatographic analysis was performed using heptane- $\mathrm{iPrOH}$ 93:7 mixture as an eluent in isocratic elution $\left(1.0 \mathrm{~mL} / \mathrm{min}, 25{ }^{\circ} \mathrm{C}\right)$ on a Reprosil ChiralMIA column $(5 \mu \mathrm{m}, 100 \times 4.6 \mathrm{~mm})$. Detector wavelength: $242 \mathrm{~nm}$. Retention times: $4.8 \mathrm{~min}$ for $(R, R)-\mathbf{1}$ and $3.4 \mathrm{~min}$ for $(S, S)$-1. Chiral separation of $(R, R)-\mathbf{2},(S, S)-\mathbf{2},(R, R)-\mathbf{3}$, $(S, S)-\mathbf{3},(R, R)-\mathbf{4}$, and $(S, S)-\mathbf{4}$ enantiomers was carried out on a PerkinElmer Series 200 liquid chromatography system. Chromatographic analysis was performed using hexane-EtOH 85:15 mixture as an eluent in isocratic elution $\left(0.8 \mathrm{~mL} / \mathrm{min}, 20^{\circ} \mathrm{C}\right)$ on a Phenomenex Lux ${ }^{\circledR}$ Cellulose-1 column $(5 \mu \mathrm{m}, 250 \times 4.6 \mathrm{~mm})$. Detector wavelength: $254 \mathrm{~nm}$. Retention times: $11.4 \mathrm{~min}$ for $(R, R)-\mathbf{2}, 10.6 \mathrm{~min}$ for $(S, S)$-2, $15.8 \mathrm{~min}$ for $(R, R)-\mathbf{3}, 14.2 \mathrm{~min}$ for $(S, S)$-3 , $7.6 \mathrm{~min}$ for $(R, R)-\mathbf{4}$, and $6.9 \mathrm{~min}$ for $(S, S)$-4. Chiral separation of $(R, R)-\mathbf{6}$ and $(S, S)-\mathbf{6}$ enantiomers was carried out on a VWR-Hitachi LaChrom Elite ${ }^{\circledR}$ liquid chromatography system. Chromatographic analysis was performed using heptane-EtOH mixture as an eluent in gradient elution $\left(5-45 \% \mathrm{EtOH}, 1.0 \mathrm{~mL} / \mathrm{min}, 40{ }^{\circ} \mathrm{C}\right.$ ) on a Reprosil Chiral-MIA column $(5 \mu \mathrm{m}, 100 \times 4.6 \mathrm{~mm})$. Detector wavelength: $235 \mathrm{~nm}$. Retention times: $7.7 \mathrm{~min}$ for $(R, R)-6$ and $6.4 \mathrm{~min}$ for $(S, S)-\mathbf{6}$. Optical rotations were taken on a Perkin-Elmer 241 polarimeter that was calibrated by measuring the optical rotations of both enantiomers of menthol. Infrared (IR) spectra were recorded on a Bruker Alpha-T FT-IR spectrometer. ${ }^{1} \mathrm{H}(500 \mathrm{MHz})$ and ${ }^{13} \mathrm{C}(125$ $\mathrm{MHz})$ NMR spectra were obtained on a Bruker DRX500 Avance spectrometer. ${ }^{1} \mathrm{H}(300 \mathrm{MHz})$ and ${ }^{13} \mathrm{C}(75.5$ MHz) NMR spectra were taken on a Bruker 300 Avance spectrometer. The signals of $\mathrm{NH}$ and $\mathrm{OH}$ protons in the ${ }^{1} \mathrm{H}$ NMR spectra were helped to identify by shaking the
NMR samples with $\mathrm{D}_{2} \mathrm{O}$. Mass spectra (LC-MS) were recorded on an Agilent 1200 Series coupled Agilent 6130 Series Quadrupole spectrometer system in electrospray ionization (ESI) mode using water $\left(1 \% \mathrm{NH}_{4} \mathrm{HCO}_{3}\right) /$ acetonitrile ( $8 \%$ water, $\left.1 \% \mathrm{NH}_{4} \mathrm{HCO}_{3}\right)$ as an eluent in gradient elution $\left(5-100 \%\right.$ acetonitrile, $\left.0.6 \mathrm{~mL} / \mathrm{min}, 40{ }^{\circ} \mathrm{C}\right)$ on a Phenomenex Gemini NX-C18 column $(3 \mu \mathrm{m}, 110 \AA$, $150 \times 3.0 \mathrm{~mm}$ ). Elemental analyses were performed in the Microanalytical Laboratory of the Department of Organic Chemistry, Institute for Chemistry, L. Eötvös University, Budapest, Hungary.

UV-vis spectra were taken on a Unicam UV4-100 spectrophotometer. Quartz cuvettes with path length of $1 \mathrm{~cm}$ were used. Fluorescence emission spectra were recorded on a Perkin-Elmer LS 50B luminescent spectrometer and were corrected by the spectrometer software. Quartz cuvettes with path length of $1 \mathrm{~cm}$ were used. Enantiomers of PEA, NEA, PGME, and PAME were prepared in our laboratory [56]. The concentrations of sensor molecules were $0.2,2$ or $20 \mu \mathrm{M}$ during the fluorescence titrations. Stability constants of the complexes were determined by global nonlinear regression analysis using SPECFIT $/ 32^{\mathrm{TM}}$ software.

\subsection{General procedure for the synthesis of sensor molecules $(R, R)-1$ and $(S, S)-1$}

A suspension of $\mathrm{NaH}$ (51 mg, $1.3 \mathrm{mmol}, 60 \%$ dispersion in mineral oil) was stirred vigorously in pure and dry THF $(0.5 \mathrm{~mL})$ under Ar for $5 \mathrm{~min}$. To this suspension was added slowly aminodiol $(R, R)-6$ or $(S, S)-6(100 \mathrm{mg}, 0.212 \mathrm{mmol})$ dissolved in pure and dry THF $(2 \mathrm{~mL})$. The mixture was stirred at $\mathrm{rt}$ for $10 \mathrm{~min}$ and at reflux temperature for $4 \mathrm{~h}$. The mixture was cooled down to $-60{ }^{\circ} \mathrm{C}$, and tetraethylene glycol ditosylate 7 [46] (138 mg, $0.275 \mathrm{mmol})$ dissolved in pure and dry THF $(3 \mathrm{~mL})$ was added in $5 \mathrm{~min}$. After addition of the ditosylate 7 the reaction mixture was allowed to warm up slowly to rt, and it was stirred at this temperature overnight. The solvent was evaporated, and the residue was dissolved in a mixture of EtOAc $(10 \mathrm{~mL})$ and brine $(4 \mathrm{~mL})$. The phases were shaken thoroughly and separated. The aqueous phase was extracted with EtOAc $(3 \times 10 \mathrm{~mL})$. The combined organic phase was dried over anhydrous $\mathrm{MgSO}_{4}$, filtered and evaporated. The crude product was purified first by column chromatography on alumina using EtOH-toluene 1:200 mixture as an eluent then by preparative TLC on silica gel using EtOAc-hexane 1:2 mixture as an eluent to give receptor $(R, R)-\mathbf{1}$ or $(S, S)$-1 as yellow crystals. 
4.2.1 (14R,18R)-14,18-Diphenyl-16-(pyren-1-ylmethyl)1,4,7,10,13-pentaoxa-16-azacyclooctadecane [ $R, R)-1]$ Yield: $44 \mathrm{mg}, 33 \%$; mp: $45-47{ }^{\circ} \mathrm{C} ; R_{\mathrm{f}}: 0.16$ (silica gel TLC, EtOAc-hexane 1:2); ee $>99 \%$; $[\alpha]_{\mathrm{D}}^{25}-23.5(c=1.00$ in acetone); IR (neat) $v_{\max } 3369$ (br, complexed $\mathrm{H}_{2} \mathrm{O}$ ), 3077 , 3052, 3028, 2862, 1602, 1586, 1491, 1451, 1417, 1348, 1296, 1245, 1097, 1022, 945, 842, 817, 754, 699, 644, $529 \mathrm{~cm}^{-1} ;{ }_{1}^{1} \mathrm{H}$ NMR $\left(300 \mathrm{MHz}\right.$, acetone- $\left.d_{6}\right) \delta 2.80-2.89(\mathrm{~m}$, $2 \mathrm{H}), 2.97$ ( $\mathrm{s}$, complexed $\mathrm{H}_{2} \mathrm{O}$ together with the $\mathrm{H}_{2} \mathrm{O}$ content of acetone- $\left.d_{6}, 1 \mathrm{H}\right), 3.17-3.28(\mathrm{~m}, 2 \mathrm{H}), 3.42-3.56(\mathrm{~m}$, $4 \mathrm{H}), 3.58-3.80(\mathrm{~m}, 12 \mathrm{H}), 4.58(\mathrm{~s}, 2 \mathrm{H}), 4.71-4.79(\mathrm{~m}, 2 \mathrm{H})$, 7.14-7.29 (m, 10H), 7.99-8.19 (m, 6H), 8.20-8.26 (m, 2H), $8.46(\mathrm{~d}, J=9 \mathrm{~Hz}, 1 \mathrm{H}) ;{ }^{13} \mathrm{C}$ NMR $(75.5 \mathrm{MHz}$, acetone- $\left.d_{6}\right) \delta 58.12,61.33,67.98,70.48,70.60,70.66,80.88$, $124.39,124.61,124.75,124.76,124.81,124.90,125.91$, $126.87,126.88,126.97,127.21,127.50,128.07,128.46$, 129.88, 130.59, 131.04, 131.38, 133.87, 141.78; MS calcd for $\mathrm{C}_{41} \mathrm{H}_{43} \mathrm{NO}_{5}: 629.3$, found $(\mathrm{M}+\mathrm{H})^{+}:$630.3; Anal. calcd for $\mathrm{C}_{41} \mathrm{H}_{43} \mathrm{NO}_{5} \cdot 0.5 \mathrm{H}_{2} \mathrm{O}: \mathrm{C} 77.09, \mathrm{H} 6.94, \mathrm{~N} 2.19$, found: C 76.70, H 6.93, N 2.14.

\subsection{2 (14S,18S)-14,18-Diphenyl-16-(pyren-1-ylmethyl)-} 1,4,7,10,13-pentaoxa-16-azacyclooctadecane [ $(S, S)$-1] Yield: $35 \mathrm{mg}, 26 \%$; ee $>99 \%$; $[\alpha]_{\mathrm{D}}^{25}+21.1(c=1.00$ in acetone). Spectral data and other physical properties of macrocycle $(S, S)$-1 were the same as those of macrocycle $(R, R)-\mathbf{1}$ reported above.

\subsection{General procedure for the synthesis of sensor molecules $(R, R)-2$ and $(S, S)-2$}

A suspension of $\mathrm{NaH}$ (102 mg, $2.55 \mathrm{mmol}, 60 \%$ dispersion in mineral oil) was stirred vigorously in pure and dry DMF $(0.5 \mathrm{~mL})$ under Ar for $5 \mathrm{~min}$. To this suspension was added slowly aminodiol $(R, R)-6$ or $(S, S)-6(200 \mathrm{mg}$, $0.424 \mathrm{mmol})$ dissolved in pure and dry DMF $(2 \mathrm{~mL})$ at $-60{ }^{\circ} \mathrm{C}$. The resulting mixture was stirred at $50{ }^{\circ} \mathrm{C}$ for $1 \mathrm{~h}$. The mixture was cooled down to $-60^{\circ} \mathrm{C}$, and ditosylate 17 (288 $\mathrm{mg}, 0.460 \mathrm{mmol})$ dissolved in pure and dry DMF (3.5 mL) was added in 5 min. After addition of the ditosylate $\mathbf{1 7}$ the reaction mixture was allowed to warm up slowly to rt, and it was stirred at this temperature overnight. The solvent was evaporated, and the residue was dissolved in a mixture of EtOAc $(30 \mathrm{~mL})$ and brine $(10 \mathrm{~mL})$. The phases were shaken thoroughly and separated. The aqueous phase was extracted with EtOAc $(2 \times 30 \mathrm{~mL})$. The combined organic phase was dried over anhydrous $\mathrm{MgSO}_{4}$, filtered and evaporated. The crude product was purified by column chromatography on alumina using hexane saturated with acetonitrile as an eluent to give receptor $(R, R)-\mathbf{2}$ or $(S, S)-\mathbf{2}$ as whitish crystals.

\subsection{1 (9R,13R)-9,13-Diphenyl-11-(pyren-1-ylmethyl)- $6,7,10,11,12,13,15,16$-octahydro-9H,22H-dibenzo[e,h]} $[1,4,10,13]$ tetra-oxa[7,16] diazacyclooctadecine $[(R, R)-2]$ Yield: $105 \mathrm{mg}, 34 \%$; mp: 88-91 ${ }^{\circ} \mathrm{C}$; $R_{\mathrm{f}}: 0.19$ (alumina TLC, EtOAc-hexane 1:25); ee $>95 \%$; $[\alpha]_{\mathrm{D}}^{25}-25.5(c=1.00$ in acetone); IR ( $\mathrm{KBr}) v_{\max } 3411$ (br, complexed $\left.\mathrm{H}_{2} \mathrm{O}\right), 3085$, 3056, 3036, 2924, 2866, 2808, 1601, 1588, 1522, 1495, $1452,1433,1346,1285,1247,1204,1156,1117,1053,1041$, 1023, 924, 848, 737, $701 \mathrm{~cm}^{-1}$; ${ }^{1} \mathrm{H}$ NMR (500 MHz, acetone- $\left.d_{6}\right) \delta$ 2.83-2.91 (m, 2H), $2.86\left(\mathrm{~s}\right.$, complexed $\mathrm{H}_{2} \mathrm{O}$, $2 \mathrm{H}), 3.37-3.45(\mathrm{~m}, 2 \mathrm{H}), 3.72-3.83(\mathrm{~m}, 4 \mathrm{H}), 4.19-4.31(\mathrm{~m}$, $4 \mathrm{H})$, the benzylic type protons give an $\mathrm{AB}$ quartet: $\delta_{\mathrm{A}} 4.52$ and $\delta_{\mathrm{B}} 4.55\left(J_{\mathrm{AB}}=14 \mathrm{~Hz}, 2 \mathrm{H}\right), 4.85-4.91(\mathrm{~m}, 2 \mathrm{H}), 6.88(\mathrm{t}$, $J=8 \mathrm{~Hz}, 2 \mathrm{H}), 6.93-7.03$ (m, 4H), 7.09 (s, 1H, NH, disappears after shaking the solution with $\left.\mathrm{D}_{2} \mathrm{O}\right), 7.12-7.20$ (m, 6H), 7.24-7.32 (m, 4H), 7.49 (d, $J=8 \mathrm{~Hz}, 2 \mathrm{H}), 7.87$ $(\mathrm{d}, J=9 \mathrm{~Hz}, 1 \mathrm{H}), 7.95-8.09(\mathrm{~m}, 5 \mathrm{H}), 8.12(\mathrm{~d}, J=8 \mathrm{~Hz}$, $1 \mathrm{H}), 8.20(\mathrm{~d}, J=8 \mathrm{~Hz}, 1 \mathrm{H}), 8.35$ (d, $J=9 \mathrm{~Hz}, 1 \mathrm{H}) ;{ }^{13} \mathrm{C}$ NMR (125 MHz, acetone- $\left.d_{6}\right) \delta 58.30,61.04,67.42,68.65$, $81.52,112.14,115.09,120.05,120.84,124.34,124.42$, $124.51,124.63,124.69,124.82,125.79,126.71,126.75$, $126.90,127.18,127.44,128.03,128.17,129.67,130.46$, $130.93,131.28,132.93,133.68,141.52,148.41$; MS calcd for $\mathrm{C}_{49} \mathrm{H}_{44} \mathrm{~N}_{2} \mathrm{O}_{4}: 724.3$, found $(\mathrm{M}+\mathrm{H})^{+}:$725.3; Anal. calcd for $\mathrm{C}_{49} \mathrm{H}_{44} \mathrm{~N}_{2} \mathrm{O}_{4} \cdot \mathrm{H}_{2} \mathrm{O}$ : C 79.22, $\mathrm{H} \mathrm{6.24,} \mathrm{N} \mathrm{3.77,} \mathrm{found:} \mathrm{C}$ 79.11, H 6.31, N 3.73 .

\subsection{2 (9S,13S)-9,13-Diphenyl-11-(pyren-1-ylmethyl)- $6,7,10,11,12,13,15,16$-octahydro-9H,22H-dibenzo[e,h]} $[1,4,10,13]$ tetra-oxa[7,16]diazacyclooctadecine $[(S, S)-2]$ Yield: $108 \mathrm{mg}, 35 \%$; ee $>99 \%$; $[\alpha]_{\mathrm{D}}^{25}+25.9(c=0.99$ in acetone). Spectral data and other physical properties of macrocycle $(S, S)$-2 were the same as those of macrocycle $(R, R)-2$ reported above.

\subsection{General procedure for the synthesis of sensor molecules $(R, R)-3$ and $(S, S)-3$}

To a stirred solution of $(R, R)-2$ or $(S, S)-2$ (50 mg, $0.069 \mathrm{mmol})$ in $\mathrm{iPr}_{2} \mathrm{O}(2 \mathrm{~mL})$ was added a mixture of $\mathrm{HCOOH}(0.30 \mathrm{~mL}, 0.37 \mathrm{~g}, 8.0 \mathrm{mmol})$ and $\mathrm{Ac}_{2} \mathrm{O}(0.68 \mathrm{~mL}$, $0.73 \mathrm{~g}, 7.2 \mathrm{mmol})$ dropwise. The reaction mixture was stirred at boiling temperature for $2 \mathrm{~h}$ and then it was allowed to cool down to rt. The volatile components were 
removed, and the residue was dissolved in a mixture of $25 \%$ aqueous $\mathrm{Me}_{4} \mathrm{NHCO}_{3}$ solution $(5 \mathrm{~mL})$ and EtOAc $(10 \mathrm{~mL})$ at $0{ }^{\circ} \mathrm{C}$. The phases were shaken thoroughly and separated. The aqueous phase was extracted with EtOAc $(3 \times 10 \mathrm{~mL})$. The combined organic phase was dried over anhydrous $\mathrm{MgSO}_{4}$, filtered and evaporated. The crude product was purified by preparative TLC on silica gel using EtOAc-hexane 1:3 mixture as an eluent to give receptor $(R, R)-\mathbf{3}$ or $(S, S)-\mathbf{3}$ as whitish crystals.

\subsection{1 (9R,13R)-9,13-Diphenyl-11-(pyren-1-ylmethyl)- $6,7,10,11,12,13,15,16$-octahydro-9H,22H-dibenzo $[e, h]$ $[1,4,10,13]$ tetraoxa[7,16]diaza-cyclooctadecine-22- carbaldehyde $[(\boldsymbol{R}, \boldsymbol{R})-3]$}

Yield: $44 \mathrm{mg}, 85 \%$; mp: $96-97^{\circ} \mathrm{C} ; R_{\mathrm{f}}: 0.33$ (silica gel TLC, EtOAc-hexane 1:3); ee $>99 \%$; $[\alpha]_{\mathrm{D}}^{25}-118.5(c=0.64$ in acetone); IR (KBr) $v_{\max } 3085,3060,3032,2926,2869$, 2809, 1688, 1596, 1499, 1451, 1332, 1272, 1244, 1103, 1045, $1021,945,917,849,751,702 \mathrm{~cm}^{-1}$; ${ }^{1} \mathrm{H}$ NMR $(500 \mathrm{MHz}$, acetone- $\left.d_{6}\right) \delta 2.64-2.73(\mathrm{~m}, 2 \mathrm{H}), 3.11-3.26(\mathrm{~m}, 2 \mathrm{H}), 3.63-3.93$ $(\mathrm{m}, 6 \mathrm{H}), 3.95-4.03(\mathrm{~m}, 1 \mathrm{H}), 4.14-4.23(\mathrm{~m}, 1 \mathrm{H})$, the benzylic type protons give an AB quartet: $\delta_{\mathrm{A}} 4.28$ and $\delta_{\mathrm{B}} 4.58$ $\left(J_{\mathrm{AB}}=13 \mathrm{~Hz}, 2 \mathrm{H}\right), 4.78-4.88(\mathrm{~m}, 2 \mathrm{H}), 6.84(\mathrm{~d}, J=8 \mathrm{~Hz}$, 1H), 6.92-7.01 (m, 2H), 7.03-7.34 (m, 15H), 7.92 (t, $J=8$ $\mathrm{Hz}, 1 \mathrm{H}), 7.99-8.11(\mathrm{~m}, 6 \mathrm{H}), 8.18$ (d, $J=8 \mathrm{~Hz}, 1 \mathrm{H}), 8.53$ $(\mathrm{s}, 1 \mathrm{H}), 8.61(\mathrm{~d}, J=9 \mathrm{~Hz}, 1 \mathrm{H}) ;{ }^{13} \mathrm{C}$ NMR $(125 \mathrm{MHz}$, acetone- $\left.d_{6}\right) \delta 55.48,60.46,63.84,68.48,68.55,69.41,70.02$, $81.16,81.69,115.23,115.29,121.25,121.82,125.23,125.36$, $125.55,125.61,125.66,125.98,126.73,127.46$ (very high, probably two ${ }^{13} \mathrm{C}$ signals together), 127.61, 127.76, 127.90, 128.06 , 128.30, 128.49, 128.86, 129.01, 129.08, 129.41, 129.71 (broad, probably two ${ }^{13} \mathrm{C}$ signals together), 130.71 , $130.80,131.57,131.86,132.10,132.44,134.38,142.54$, 142.65, 154.62, 155.43, 162.92; MS calcd for $\mathrm{C}_{50} \mathrm{H}_{44} \mathrm{~N}_{2} \mathrm{O}_{5}$ : 752.3, found $(\mathrm{M}+\mathrm{H})^{+}$: 753.3; Anal. calcd for $\mathrm{C}_{50} \mathrm{H}_{44} \mathrm{~N}_{2} \mathrm{O}_{5}$ : C 79.76, H 5.89, N 3.72, found: C 79.44, H 5.83, N 3.47.

\subsection{2 (9S,13S)-9,13-Diphenyl-11-(pyren-1-ylmethyl)- $6,7,10,11,12,13,15,16-0 c t a h y d r o-9 H, 22 H$-dibenzo[e,h]} $[1,4,10,13]$ tetraoxa[7,16] diaza-cyclooctadecine-22carbaldehyde $[(S, S)-3]$

Yield: $39 \mathrm{mg}, 76 \%$; mp: $95-96{ }^{\circ} \mathrm{C}$; ee $>99 \%$; $[\alpha]_{\mathrm{D}}^{25}+117.1$ ( $c=0.62$ in acetone). Spectral data and other physical properties of macrocycle $(S, S)$-3 were the same as those of macrocycle $(R, R)-\mathbf{3}$ reported above.
4.5 Procedures for the synthesis of sensor molecules $(R, R)-4$ and $(S, S)-4$

4.5.1 Procedure for the synthesis of sensor molecules $(R, R)-4$ and $(S, S)-4$ starting from ditosylate 18 and aminodiol $(R, R)-6$ or $(S, S)-6$

To a suspension of $\mathrm{NaH}(51 \mathrm{mg}, 1.3 \mathrm{mmol}, 60 \%$ dispersion in mineral oil) in pure and dry DMF $(0.5 \mathrm{~mL})$ was added slowly aminodiol $(R, R)-\mathbf{6}$ or $(S, S)-6(100 \mathrm{mg}, 0.212 \mathrm{mmol})$ dissolved in pure and dry DMF $(2 \mathrm{~mL})$ at $-60^{\circ} \mathrm{C}$ under Ar. The resulting mixture was stirred at $50{ }^{\circ} \mathrm{C}$ for $1 \mathrm{~h}$. The mixture was cooled down to $-60{ }^{\circ} \mathrm{C}$, and ditosylate $\mathbf{1 8}$ (136 $\mathrm{mg}, 0.223 \mathrm{mmol})$ dissolved in pure and dry DMF $(2 \mathrm{~mL})$ was added in $5 \mathrm{~min}$. After addition of the ditosylate $\mathbf{1 8}$ the reaction mixture was allowed to warm up slowly to $\mathrm{rt}$, and it was stirred at this temperature overnight. The solvent was evaporated, and the residue was dissolved in a mixture of $\mathrm{Et}_{2} \mathrm{O}(20 \mathrm{~mL})$ and water $(8 \mathrm{~mL})$. The phases were shaken thoroughly and separated. The aqueous phase was extracted with $\mathrm{Et}_{2} \mathrm{O}(2 \times 20 \mathrm{~mL})$. The combined organic phase was dried over anhydrous $\mathrm{MgSO}_{4}$, filtered and evaporated. The crude product was purified by column chromatography on alumina using EtOAc-hexane 1:50 mixture as an eluent to give receptor $(R, R)-\mathbf{4}$ or $(S, S)-\mathbf{4}$ as yellow crystals.

\subsubsection{1 (9R,13R)-22-Methyl-9,13-diphenyl-11-} (pyren-1-ylmethyl)-6,7,10,11,12,13,15,16-octahydro$9 H, 22 H$-dibenzo $[e, h][1,4,10,13]$ tetraoxa[7,16]diazacyclooctadecine $[(\boldsymbol{R}, \boldsymbol{R})-4]$

Yield: $45 \mathrm{mg}, 29 \%$; mp: $60-62{ }^{\circ} \mathrm{C} ; R_{\mathrm{f}}: 0.63$ (silica gel TLC, EtOAc-toluene 1:3); ee $>98 \% ;[\alpha]_{\mathrm{D}}^{25}-46.3(c=1.00$ in acetone); IR (neat) $v_{\max } 3394$ (br, complexed $\mathrm{H}_{2} \mathrm{O}$ ), 3080, 3050, 3030, 2922, 2861, 2804, 1587, 1498, 1448, 1336, 1253, 1107, 1041, 1019, 917, 847, 817, 739, 700, 639, 614 $\mathrm{cm}^{-1}$; ${ }^{1} \mathrm{H}$ NMR $\left(300 \mathrm{MHz}\right.$, acetone- $\left.d_{6}\right) \delta 2.10$ (s, complexed $\left.\mathrm{H}_{2} \mathrm{O}, 2 \mathrm{H}\right), 2.72-2.83(\mathrm{~m}, 2 \mathrm{H}), 3.12-3.21(\mathrm{~m}, 2 \mathrm{H})$, 3.21 (s, 3H), 3.26-3.36 (m, 2H), 3.50-3.60 (m, 2H), 3.92$4.02(\mathrm{~m}, 2 \mathrm{H}), 4.26-4.36(\mathrm{~m}, 2 \mathrm{H})$, the benzylic type protons give an $\mathrm{AB}$ quartet: $\delta_{\mathrm{A}} 4.42$ and $\delta_{\mathrm{B}} 4.52\left(J_{\mathrm{AB}}=13 \mathrm{~Hz}\right.$, $2 \mathrm{H}), 4.78-4.88(\mathrm{~m}, 2 \mathrm{H}), 6.86-7.08(\mathrm{~m}, 8 \mathrm{H}), 7.14-7.30$ $(\mathrm{m}, 10 \mathrm{H}), 7.86-8.24(\mathrm{~m}, 8 \mathrm{H}), 8.42(\mathrm{~d}, J=9 \mathrm{~Hz}, 1 \mathrm{H}) ;{ }^{13} \mathrm{C}$ NMR (75.5 MHz, acetone- $\left.d_{6}\right) \delta 38.53,59.70,61.69,67.74$, 69.31, 80.97, 115.47, 121.01, 121.44, 122.88, 124.36, 124.55, $124.72,124.74,124.75,124.92,125.86,126.71,126.79$, $126.83,127.14,127.48,128.06,128.32,129.79,130.59$, 
130.99, 131.33, 133.74, 140.98, 141.68, 152.43; MS calcd for $\mathrm{C}_{50} \mathrm{H}_{46} \mathrm{~N}_{2} \mathrm{O}_{4}$ : 738.4, found $(\mathrm{M}+\mathrm{H})^{+}$: 739.4; Anal. calcd for $\mathrm{C}_{50} \mathrm{H}_{46} \mathrm{~N}_{2} \mathrm{O}_{4} \cdot \mathrm{H}_{2} \mathrm{O}: \mathrm{C} 79.34, \mathrm{H} 6.39$, N 3.70, found: C 78.92, H 6.73, N 3.45.

\subsubsection{2 (9S,13S)-22-Methyl-9,13-diphenyl-11- (pyren-1-ylmethyl)-6,7,10,11,12,13,15,16-octahydro-

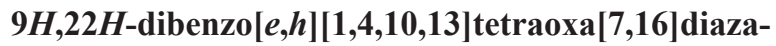 cyclooctadecine $[(S, S)-4]$}

Yield: $48 \mathrm{mg}, 31 \%$; ee $>99 \%$; $[\alpha]_{\mathrm{D}}^{29}+43.1(c=0.89$ in acetone). Spectral data and other physical properties of macrocycle $(S, S)-\mathbf{4}$ were the same as those of macrocycle $(R, R)-4$ reported above.

\subsubsection{Procedure for the synthesis of sensor molecule} $(S, S)-4$ starting from diphenol 10 and ditosylate $(S, S)-23$ To a suspension of diphenol derivative $\mathbf{1 0}$ (24 $\mathrm{mg}$, $0.11 \mathrm{mmol}$ ) and finely powdered anhydrous $\mathrm{K}_{2} \mathrm{CO}_{3}$ (115 mg, $0.83 \mathrm{mmol})$ in dry MeCN (2 mL) was added a solution of ditosylate $(S, S)-23(90 \mathrm{mg}, 0.10 \mathrm{mmol})$ in dry $\mathrm{MeCN}$ (4 mL) under Ar. The resulting mixture was stirred vigorously at $50{ }^{\circ} \mathrm{C}$, and after the reaction was complete, it was allowed to cool to rt. The solvent was evaporated, and the residue was taken up in a mixture of water $(20 \mathrm{~mL})$ and $\mathrm{Et}_{2} \mathrm{O}(25 \mathrm{~mL})$. The phases were shaken well and separated. The aqueous phase was extracted with $\mathrm{Et}_{2} \mathrm{O}(2 \times 25 \mathrm{~mL})$. The combined organic phase was dried over anhydrous $\mathrm{MgSO}_{4}$, filtered, and the solvent was removed. The crude product was purified by preparative TLC on alumina using EtOAc-hexane 1:20 mixture as an eluent to give receptor $(S, S)-4(15 \mathrm{mg}, 20 \%)$ as yellow crystals. Macrocycle $(S, S)-4$ had the same physical properties and spectral data as the one prepared above from ditosylate $\mathbf{1 8}$ and aminodiol $(S, S)-\mathbf{6}$.

\subsection{Pyren-1-ylmethanamine (5)}

Commercially available pyren-1-ylmethanamine hydrochloride (1.00 g, $3.73 \mathrm{mmol}$ ) and $\mathrm{NaOH}$ (154 mg, $3.85 \mathrm{mmol}$ ) were stirred in EtOH $(10 \mathrm{~mL})$ at $\mathrm{rt}$ under Ar. The solvent was removed, and the residue was dissolved in a mixture of $5 \%$ aqueous $\mathrm{NaOH}$ solution $(25 \mathrm{~mL})$ and $\mathrm{CH}_{2} \mathrm{Cl}_{2}(50 \mathrm{~mL})$. The phases were shaken well and separated. The aqueous phase was extracted with $\mathrm{CH}_{2} \mathrm{Cl}_{2}(3 \times 50 \mathrm{~mL})$. The combined organic phase was dried over anhydrous $\mathrm{MgSO}_{4}$, filtered, and the solvent was evaporated to give free amine $\mathbf{5}$ [45] (845 mg, $98 \%)$ as a white solid.

\subsection{General procedure for the synthesis of aminodiols} $(R, R)-6$ and $(S, S)-6$ containing a pyrene unit

Pyren-1-ylmethanamine (5, $800 \mathrm{mg}, 3.46 \mathrm{mmol})$ and $(R)-2-$ phenyloxirane or $(S)$-2-phenyloxirane $(0.99 \mathrm{~mL}, 1.0 \mathrm{~g}, 8.6$ $\mathrm{mmol})$ were dissolved in dry $\mathrm{MeOH}(3 \mathrm{~mL})$ and heated in a sealed tube at $80^{\circ} \mathrm{C}$ for $4 \mathrm{~h}$. The solvent was evaporated, and the residue was purified by column chromatography on silica gel using EtOAc-hexane 1:4 mixture as an eluent. The product was recrystallized from xylene to give aminodiol $(R, R)-\mathbf{6}$ or $(S, S)-\mathbf{6}$ as white crystals.

\subsection{1 (1R,1'R)-2,2'-[(Pyren-1-ylmethyl)azanediyl]bis (1-phenylethanol) $[(\boldsymbol{R}, \boldsymbol{R})-6]$}

Yield: $932 \mathrm{mg}, 57 \%$; mp: $166-167{ }^{\circ} \mathrm{C}$ (xylene); $R_{\mathrm{f}}: 0.44$ (silica gel TLC, EtOAc-hexane 1:2); ee $>99 \%$; $[\alpha]_{\mathrm{D}}^{25}$ -147.5 ( $c=1.00$ in acetone); IR (KBr) $v_{\max } 3582,3526$, 3494, 3079, 3049, 3029, 2947, 2860, 2823, 1602, 1586, 1491, 1453, 1379, 1326, 1312, 1266, 1243, 1194, 1091, 1063, 1024, 894, 851, 763, 753, 702, 634, $554 \mathrm{~cm}^{-1}$; ${ }^{1} \mathrm{H}$ NMR $\left(500 \mathrm{MHz}\right.$, acetone- $\left.d_{6}\right) \delta 2.83-2.97(\mathrm{~m}, 4 \mathrm{H})$, the benzylic type protons give an $\mathrm{AB}$ quartet: $\delta_{\mathrm{A}} 4.44$ and $\delta_{\mathrm{B}} 4.67$ $\left(J_{\mathrm{AB}}=13 \mathrm{~Hz}, 2 \mathrm{H}\right), 4.57$ (s, 2H, OH, disappears after shaking the solution with $\left.\mathrm{D}_{2} \mathrm{O}\right), 4.71-4.76(\mathrm{~m}, 2 \mathrm{H}), 7.14-7.19$ (m, 2H), 7.20-7.29 (m, 8H), 8.02 (t, $J=8 \mathrm{~Hz}, 1 \mathrm{H}), 8.08-$ $8.13(\mathrm{~m}, 3 \mathrm{H}), 8.15-8.26(\mathrm{~m}, 4 \mathrm{H}), 8.70(\mathrm{~d}, J=9 \mathrm{~Hz}, 1 \mathrm{H})$; ${ }^{13} \mathrm{C}$ NMR (125 MHz, acetone- $\left.d_{6}\right) \delta 58.85,63.45,70.86$, $124.30,124.50,124.66,124.87,125.06,125.13,125.89$, $126.05,126.90,127.13,127.29,127.51,127.97,128.68$, $130.05,130.95,131.02,131.38,133.09,143.71$; MS calcd for $\mathrm{C}_{33} \mathrm{H}_{29} \mathrm{NO}_{2}: 471.2$, found $(\mathrm{M}+\mathrm{H})^{+}$: 472.2; Anal. calcd for $\mathrm{C}_{33} \mathrm{H}_{29} \mathrm{NO}_{2}$ : C 84.05, H 6.20, N 2.97, found: C 83.70, H $6.27, \mathrm{~N} 2.79$.

\subsection{2 (1S,1'S)-2,2'-[(Pyren-1-ylmethyl)azanediyl]bis(1- phenylethanol) $[(S, S)-6]$}

Yield: $801 \mathrm{mg}, 49 \%$; ee $>99 \%$; $[\alpha]_{\mathrm{D}}^{25}+148.2(c=1.00$ in acetone). Spectral data and other physical properties of aminodiol $(S, S)-6$ were the same as those of aminodiol $(R, R)-6$ reported above.

4.8 2-Methoxy- $\mathrm{N}$-(2-methoxyphenyl)- $\mathrm{N}$-methylaniline (9) A suspension of $\mathrm{NaH}(6.28 \mathrm{~g}, 157 \mathrm{mmol}, 60 \%$ dispersion in mineral oil) was stirred vigorously in pure and dry THF $(20 \mathrm{~mL})$ under Ar for $5 \mathrm{~min}$. To this suspension was slowly added secondary amine 8 [47] (12.0 g, $52.3 \mathrm{mmol})$ dissolved in pure and dry $\mathrm{THF}(70 \mathrm{~mL})$ at $0{ }^{\circ} \mathrm{C}$. 
The resulting mixture was refluxed for $30 \mathrm{~min}$ then a solution of methyl iodide $(3.9 \mathrm{~mL}, 8.9 \mathrm{~g}, 63 \mathrm{mmol})$ in pure and dry THF $(10 \mathrm{~mL})$ was added dropwise at $\mathrm{rt}$. The reaction mixture was stirred for $2 \mathrm{~h}$ at $\mathrm{rt}$. The volatile components were removed, and the residue was dissolved in a mixture of water $(300 \mathrm{~mL})$ and $\mathrm{Et}_{2} \mathrm{O}(300 \mathrm{~mL})$. The phases were shaken well and separated. The aqueous phase was extracted with $\mathrm{Et}_{2} \mathrm{O}(2 \times 300 \mathrm{~mL})$. The combined organic phase was dried over anhydrous $\mathrm{MgSO}_{4}$, filtered and evaporated. The crude product was purified by column chromatography on silica gel using EtOAc-hexane 1:20 mixture as an eluent to yield amine $9(12.1 \mathrm{~g}, 95 \%)$ as white crystals. Mp: $54-55{ }^{\circ} \mathrm{C}$; $R_{\mathrm{f}}: 0.62$ (silica gel TLC, EtOAchexane 1:4); IR (KBr) $v_{\max } 3082,3069,3060,3030,3003$, 2957, 2875, 2850, 2834, 2802, 1585, 1500, 1464, 1455, $1434,1360,1332,1302,1251,1181,1133,1121,1101,1026$, $872,802,763,757,749,714,698,610,594,571,564,541$, $510,476 \mathrm{~cm}^{-1}$; ${ }^{1} \mathrm{H}$ NMR $\left(500 \mathrm{MHz}, \mathrm{CDCl}_{3}\right) \delta 3.18(\mathrm{~s}, 3 \mathrm{H})$, $3.70(\mathrm{~s}, 6 \mathrm{H}), 6.86(\mathrm{~d}, J=8 \mathrm{~Hz}, 2 \mathrm{H}), 6.87$ (t, $J=8 \mathrm{~Hz}, 2 \mathrm{H})$, $6.94(\mathrm{~d}, J=8 \mathrm{~Hz}, 2 \mathrm{H}), 7.02(\mathrm{t}, J=8 \mathrm{~Hz}, 2 \mathrm{H}) ;{ }^{13} \mathrm{C} \mathrm{NMR}$ $\left(75.5 \mathrm{MHz}, \mathrm{CDCl}_{3}\right) \delta 39.98,55.51,111.76,120.72,121.65$, 123.29, 140.32, 152.80; MS calcd for $\mathrm{C}_{15} \mathrm{H}_{17} \mathrm{NO}_{2}: 243.1$, found $(\mathrm{M}+\mathrm{H})^{+}:$244.1; Anal. calcd for $\mathrm{C}_{15} \mathrm{H}_{17} \mathrm{NO}_{2}$ : C 74.05, H 7.04, N 5.76, found: C 74.16, H 7.26, N 5.39.

\subsection{2,2'-(Methylazanediyl)diphenol (10)}

Dimethoxy derivative 9 (9.24 g, $37.9 \mathrm{mmol})$ was dissolved in chlorobenzene $(93 \mathrm{~mL})$ under Ar then anhydrous $\mathrm{AlCl}_{3}$ (20.3 g, $152 \mathrm{mmol}$ ) was added, and the resulting mixture was stirred at $90{ }^{\circ} \mathrm{C}$ for $7 \mathrm{~h}$. After the reaction was complete, the mixture was allowed to cool to $\mathrm{rt}$, and poured into ice-water $(138 \mathrm{~mL})$. Concentrated aqueous $\mathrm{HCl}$ solution $(12.5 \mathrm{~mL})$ was added, and the resulting mixture was stirred for $30 \mathrm{~min}$. The $\mathrm{pH}$ of the mixture was adjusted to 8 with $\mathrm{NaHCO}_{3}$. The precipitate was filtered off, washed with water $(150 \mathrm{~mL})$, and dried. The crude product was recrystallized from toluene to give diphenol $\mathbf{1 0}$ (6.24 g, $76 \%$ ) as white crystals. Mp: $143-145^{\circ} \mathrm{C}$ (toluene); $R_{\mathrm{f}}: 0.55$ (silica gel TLC, EtOAc-toluene 1:5); IR (KBr) $v_{\max } 3365$, 3335, 3067, 3053, 3034, 2976, 2944, 2881, 2864, 2842, 2797, 2694, 1584, 1509, 1493, 1470, 1452, 1438, 1349, 1285, $1259,1227,1192,1177,1160,1109,1027,832,797,752$, 747, 701, 597, 488, $436 \mathrm{~cm}^{-1} ;{ }^{1} \mathrm{H} \mathrm{NMR}\left(500 \mathrm{MHz}, \mathrm{CDCl}_{3}\right)$ $\delta 3.12$ (s, 3H), 5.68 (br s, $2 \mathrm{H}, \mathrm{OH}$, disappears after shaking the solution with $\left.\mathrm{D}_{2} \mathrm{O}\right), 6.92(\mathrm{t}, J=8 \mathrm{~Hz}, 2 \mathrm{H}), 6.94(\mathrm{~d}$, $J=8 \mathrm{~Hz}, 2 \mathrm{H}), 7.09$ (t, $J=8 \mathrm{~Hz}, 2 \mathrm{H}), 7.12$ (d, $J=8 \mathrm{~Hz}$, $2 \mathrm{H}) ; 13 \mathrm{C} \mathrm{NMR}\left(125 \mathrm{MHz}, \mathrm{CDCl}_{3}\right) \delta 41.95,116.06,121.05$,
122.53, 125.93, 137.11, 149.98; MS calcd for $\mathrm{C}_{13} \mathrm{H}_{13} \mathrm{NO}_{2}$ : 215.1, found $(\mathrm{M}+\mathrm{H})^{+}:$216.1; Anal. calcd for $\mathrm{C}_{13} \mathrm{H}_{13} \mathrm{NO}_{2}$ : C 72.54, H 6.09, N 6.51, found: C 72.19, H 6.23, N 6.23.

\subsection{General procedure for the synthesis of precursors 13 and 14 containing benzyl protecting groups}

To a solution of formamide derivative 11 [50] (2.29 g, $10.0 \mathrm{mmol})$ or diphenol 10 (2.15 g, $10.0 \mathrm{mmol})$ in dry MeCN (66 mL) tosylate 12 [51] (6.74 g, $22.0 \mathrm{mmol})$ and finely powdered anhydrous $\mathrm{K}_{2} \mathrm{CO}_{3}(11 \mathrm{~g}$, $80 \mathrm{mmol})$ were added under Ar. The resulting suspension was stirred vigorously, refluxed, and after the reaction was complete, it was allowed to cool to rt. The mixture was filtered, and the precipitate was washed with $\mathrm{MeCN}(3 \times 15 \mathrm{~mL})$. The solvent was evaporated from the combined MeCN solution, and the residue was taken up in a mixture of water (75 mL) and $\mathrm{CH}_{2} \mathrm{Cl}_{2}(150 \mathrm{~mL})$. The phases were shaken well and separated. The aqueous phase was extracted with $\mathrm{CH}_{2} \mathrm{Cl}_{2}(2 \times 150 \mathrm{~mL})$. The combined organic phase was dried over anhydrous $\mathrm{MgSO}_{4}$, filtered, and the solvent was removed. The crude products were purified as described below for each compound.

\subsection{1 $N, N$-Bis $\{2-[2-($ benzyloxy)ethoxy]phenyl\} formamide (13)}

Starting from formamide derivative 11 [50]. The crude product was purified first by column chromatography on silica gel using EtOAc-toluene 1:5 mixture as an eluent then by recrystallization from $\mathrm{MeOH}$ to yield formamide derivative 13 (3.83 g, $77 \%$ ) as pale brown crystals. Mp: $75-76{ }^{\circ} \mathrm{C}(\mathrm{MeOH}) ; R_{\mathrm{f}}: 0.74$ (silica gel TLC, EtOAc-toluene 1:1); IR (KBr) $v_{\text {max }} 3083,3064,3034,3023,3012,2937$, 2926, 2876, 2857, 2848, 2806, 2774, 2753, 1680, 1595, $1503,1456,1445,1356,1333,1299,1284,1248,1205$, 1100, 1024, 932, 923, 857, 765, 748, 701, 676, $603 \mathrm{~cm}^{-1}$; ${ }^{1} \mathrm{H}$ NMR (500 MHz, $\left.\mathrm{CDCl}_{3}\right) \delta 3.78(\mathrm{t}, J=5 \mathrm{~Hz}, 2 \mathrm{H}), 3.81$ (t, $J=5 \mathrm{~Hz}, 2 \mathrm{H}), 4.16$ (t, $J=5 \mathrm{~Hz}, 4 \mathrm{H}), 4.57$ (s, 2H), 4.60 $(\mathrm{s}, 2 \mathrm{H}), 6.81$ (t, $J=8 \mathrm{~Hz}, 1 \mathrm{H}), 6.87$ (t, $J=8 \mathrm{~Hz}, 1 \mathrm{H}), 6.95$ $(\mathrm{d}, J=8 \mathrm{~Hz}, 1 \mathrm{H}), 6.96(\mathrm{~d}, J=8 \mathrm{~Hz}, 1 \mathrm{H}), 7.18-7.24(\mathrm{~m}, 2 \mathrm{H})$, 7.26-7.42 (m, 12H), $8.44(\mathrm{~s}, 1 \mathrm{H}) ;{ }^{13} \mathrm{C}$ NMR (125 MHz, $\left.\mathrm{CDCl}_{3}\right) \delta 68.17,68.34,68.69,68.83,73.40,73.68,113.19$, 113.50, 121.27 (very high, probably two ${ }^{13} \mathrm{C}$ signals together), 127.77, 127.81, 127.84, 127.91, 128.52, 128.60, $128.67,129.06,129.26,129.30,130.17,130.94,138.16$, 138.34, 154.38, 154.51, 163.58; MS calcd for $\mathrm{C}_{31} \mathrm{H}_{31} \mathrm{NO}_{5}$ : 497.2, found $(\mathrm{M}+\mathrm{H})^{+}$: 498.2; Anal. calcd for $\mathrm{C}_{31} \mathrm{H}_{31} \mathrm{NO}_{5}$ : C 74.83, H 6.28, N 2.81, found: C 74.56, H 6.31, N 2.96. 


\subsubsection{2-[2-(Benzyloxy)ethoxy]- $N$-\{2-[2-(benzyloxy)} ethoxy]phenyl $\}-N$-methylaniline (14)

Starting from diphenol 10. The crude product was purified by column chromatography on silica gel using EtOAchexane 1:10 mixture as an eluent to yield tertiary amine $\mathbf{1 4}$ (3.77 g, $78 \%$ ) as a pale yellow oil. $R_{\mathrm{f}}: 0.32$ (silica gel TLC, EtOAc-hexane 1:5); IR (neat) $v_{\max } 3078,3060,3028,2925$, 2859, 2808, 1587, 1496, 1448, 1357, 1252, 1238, 1103, 1040, 1027, 928, 914, 863, 733, 696, 606, $459 \mathrm{~cm}^{-1}$; ${ }^{1} \mathrm{H} \mathrm{NMR}$ $\left(500 \mathrm{MHz}, \mathrm{CDCl}_{3}\right) \delta 3.27(\mathrm{~s}, 3 \mathrm{H}), 3.50(\mathrm{t}, J=5 \mathrm{~Hz}, 4 \mathrm{H})$, $4.04(\mathrm{t}, J=5 \mathrm{~Hz}, 4 \mathrm{H}), 4.46$ (s, 4H), 6.85-6.92 (m, 4H), 6.94$7.01(\mathrm{~m}, 4 \mathrm{H}), 7.28-7.36(\mathrm{~m}, 10 \mathrm{H}) ;{ }^{13} \mathrm{C}$ NMR (75.5 MHz, $\left.\mathrm{CDCl}_{3}\right) \delta 39.97,68.05,68.78,73.25,114.30,121.47,121.73$, $122.89,127.60,127.72,128.36,138.32,140.68,151.86$; MS calcd for $\mathrm{C}_{31} \mathrm{H}_{33} \mathrm{NO}_{4}$ : 483.2, found $(\mathrm{M}+\mathrm{H})^{+}$: 484.2; Anal. calcd for $\mathrm{C}_{31} \mathrm{H}_{33} \mathrm{NO}_{4}$ : C 76.99, $\mathrm{H}$ 6.88, N 2.90, found: C 76.81, H 7.17, N 2.85.

\subsection{General procedure for the synthesis of diols $\mathbf{1 5}$ and $\mathbf{1 6}$} Formamide derivative $\mathbf{1 3}$ (4.98 g, $10.0 \mathrm{mmol})$ or tertiary amine 14 (4.84 g, $10.0 \mathrm{mmol})$ containing benzyl protecting groups was hydrogenated in $\mathrm{MeOH}(200 \mathrm{~mL})$ in the presence of $\mathrm{Pd} / \mathrm{C}$ catalyst $(500 \mathrm{mg}, 10 \%$ palladium on charcoal, activated). After the reaction was complete, the catalyst was filtered off and the volatile components were evaporated to yield diol 15 (3.11 g, $98 \%$ ) or 16 (3.03 g, $100 \%$ ) as white solids. Smaller amounts were recrystallized from toluene for analytical studies.

\subsection{1 $\mathrm{N}, \mathrm{N}$-Bis[2-(2-hydroxyethoxy)phenyl]formamide(15)} Starting from formamide derivative 13. Mp: $137{ }^{\circ} \mathrm{C}$ (toluene); $R_{\mathrm{f}}: 0.13$ (silica gel TLC, EtOAc-toluene 2:1); IR $(\mathrm{KBr}) v_{\text {max }} 3392$ (br, OH), 3074, 3045, 3028, 2941, 2873, 2782, 1685, 1594, 1500, 1479, 1449, 1342, 1282, 1233, 1077, 1049, 1032, 920, 755, $673 \mathrm{~cm}^{-1}$; ${ }^{1} \mathrm{H}$ NMR (500 MHz, $\mathrm{CDCl}_{3}$ ) $\delta 3.04$ (br s, $2 \mathrm{H}, \mathrm{OH}$, disappears after shaking the solution with $\left.\mathrm{D}_{2} \mathrm{O}\right), 3.70$ (t, $\left.J=4 \mathrm{~Hz}, 2 \mathrm{H}\right), 3.80$ (t, $J=4 \mathrm{~Hz}$, $2 \mathrm{H}), 3.96(\mathrm{t}, J=4 \mathrm{~Hz}, 2 \mathrm{H}), 4.24(\mathrm{t}, J=4 \mathrm{~Hz}, 2 \mathrm{H}), 6.90-6.95$ (m, 2H), 6.98-7.03 (m, 2H), 7.04-7.08 (m, 1H), 7.22-7.32 (m, 3H), $8.42(\mathrm{~s}, 1 \mathrm{H}) ;{ }^{13} \mathrm{C} \mathrm{NMR}\left(125 \mathrm{MHz}, \mathrm{CDCl}_{3}\right) \delta 60.80$, 60.97, 70.08, 71.09, 113.30, 113.80, 121.30, 121.45, 127.87, 128.12 , 128.69, 129.07, 129.12, 130.33, 153.29, 153.62, 162.60; MS calcd for $\mathrm{C}_{17} \mathrm{H}_{19} \mathrm{NO}_{5}: 317.1$, found $(\mathrm{M}+\mathrm{H})^{+}$: 318.1; Anal. calcd for $\mathrm{C}_{17} \mathrm{H}_{19} \mathrm{NO}_{5}$ : C 64.34, $\mathrm{H}$ 6.04, $\mathrm{N} 4.41$, found: C 64.16, H 6.04, N 4.12.

\subsubsection{2,2'-\{[(Methylazanediyl)bis(2,1-phenylene)] bis(oxy)\}bis(ethan-1-ol) (16)}

Starting from tertiary amine 14. Mp: $85-86{ }^{\circ} \mathrm{C}$ (toluene); $R_{\mathrm{f}}: 0.28$ (silica gel TLC, EtOAc-hexane 2:1); IR $(\mathrm{KBr}) v_{\max } 3442,3384$ (br, OH), 3069, 3025, 3006, 2974, 2944, 2931, 2862, 1588, 1500, 1452, 1366, 1340, 1258, 1243, 1084, 1046, 921, 762, 754, 747, $614 \mathrm{~cm}^{-1}$; ${ }^{1} \mathrm{H}$ NMR $\left(300 \mathrm{MHz}, \mathrm{CDCl}_{3}\right) \delta 3.23(\mathrm{~s}, 3 \mathrm{H}), 3.69$ (t, $\left.J=4 \mathrm{~Hz}, 4 \mathrm{H}\right)$, 4.08 (t, $J=4 \mathrm{~Hz}, 4 \mathrm{H}$ ), 4.29 (br s, 2H, OH, disappears after shaking the solution with $\left.\mathrm{D}_{2} \mathrm{O}\right), 6.89-7.03(\mathrm{~m}, 6 \mathrm{H})$, 7.04-7.12 (m, 2H); 13C NMR (75.5 MHz, $\left.\mathrm{CDCl}_{3}\right) \delta 40.66$, 61.03, 72.10, 115.21, 122.01, 122.08, 124.38, 141.36, 151.88; MS calcd for $\mathrm{C}_{17} \mathrm{H}_{21} \mathrm{NO}_{4}$ : 303.2 , found $(\mathrm{M}+\mathrm{H})^{+}$: 304.2; Anal. calcd for $\mathrm{C}_{17} \mathrm{H}_{21} \mathrm{NO}_{4}$ : C 67.31, $\mathrm{H}$ 6.98, N 4.62, found: C 67.60, H 7.33, N 4.44 .

\section{$4.12\{[($ Formylazanediyl)bis(2,1-phenylene) $]$ bis(oxy)\}} bis(ethane-2,1-diyl) bis(4-methylbenzenesulfonate) (17) To a solution of diol 15 (1.58 g, $4.99 \mathrm{mmol})$ in $\mathrm{CH}_{2} \mathrm{Cl}_{2}$ (32 mL) was added tosyl chloride (2.38 g, $12.5 \mathrm{mmol})$ followed by $\mathrm{Et}_{3} \mathrm{~N}(8.7 \mathrm{~mL}, 60 \mathrm{mmol})$ under Ar, and the resulting mixture was stirred at $\mathrm{rt}$ for $21 \mathrm{~h}$. After the reaction was complete, $\mathrm{CH}_{2} \mathrm{Cl}_{2}(120 \mathrm{~mL})$ and water $(80 \mathrm{~mL})$ were added to the reaction mixture. The phases were shaken well and separated. The aqueous phase was extracted with $\mathrm{CH}_{2} \mathrm{Cl}_{2}$ $(3 \times 100 \mathrm{~mL})$. The combined organic phase was shaken successively with $5 \%$ aqueous $\mathrm{HCl}$ solution $(160 \mathrm{~mL})$ and water $(2 \times 80 \mathrm{~mL})$ then dried over anhydrous $\mathrm{MgSO}_{4}$, filtered, and the solvent was evaporated. The crude product was purified by recrystallization from $\mathrm{CH}_{2} \mathrm{Cl}_{2}-\mathrm{MeOH}$ mixture to give ditosylate 17 (2.85 g, $91 \%$ ) as white crystals. Mp: $175^{\circ} \mathrm{C}\left(\mathrm{CH}_{2} \mathrm{Cl}_{2}-\mathrm{MeOH}\right) ; R_{\mathrm{f}}: 0.58$ (silica gel TLC, EtOAc-toluene 1:3); IR (KBr) $v_{\max } 3080,3069,3031,2961$, 2887, 2801, 2774, 1677, 1595, 1505, 1454, 1376, 1360, 1332, 1282, 1190, 1175, 1124, 1097, 1069, 1031, 941, 932, 918, 819, 783, 756, 663, 572, 553, 504, 497, $432 \mathrm{~cm}^{-1}$; ${ }^{1} \mathrm{H}$ NMR $\left(300 \mathrm{MHz}, \mathrm{CDCl}_{3}\right) \delta 2.41(\mathrm{~s}, 3 \mathrm{H}), 2.43(\mathrm{~s}, 3 \mathrm{H}), 4.09-4.16$ $(\mathrm{m}, 2 \mathrm{H}), 4.17-4.23(\mathrm{~m}, 2 \mathrm{H}), 4.24-4.34(\mathrm{~m}, 4 \mathrm{H}), 6.80-$ $7.04(\mathrm{~m}, 4 \mathrm{H}), 7.18-7.38(\mathrm{~m}, 8 \mathrm{H}), 7.76$ (d, $J=8 \mathrm{~Hz}, 2 \mathrm{H})$, 7.79 (d, $J=8 \mathrm{~Hz}, 2 \mathrm{H}), 8.24$ (s, 1H); ${ }^{13} \mathrm{C} \mathrm{NMR}(125 \mathrm{MHz}$, $\left.\mathrm{CDCl}_{3}\right) \delta 21.78,21.82,66.29,66.47,67.86,68.35,113.28$, $113.53,121.91,122.07,128.12,128.15,128.92,129.07$, $129.10,129.23,129.95,130.08,130.22,130.72,132.81$, $132.99,145.15,145.26,153.47,153.65,163.02$; MS calcd for $\mathrm{C}_{31} \mathrm{H}_{31} \mathrm{NO}_{9} \mathrm{~S}_{2}: 625.1$, found $(\mathrm{M}+\mathrm{H})^{+}: 626.1$; Anal. calcd 
for $\mathrm{C}_{31} \mathrm{H}_{31} \mathrm{NO}_{9} \mathrm{~S}_{2}$ : C 59.51, H 4.99, N 2.24, found: C 59.46, H 4.90, N 2.09.

\section{$4.13\{[($ Methylazanediyl)bis(2,1-phenylene) $)]$ bis(oxy)\} bis(ethane-2,1-diyl) bis(4-methylbenzenesulfonate) (18)} To a solution of diol $\mathbf{1 6}(1.00 \mathrm{~g}, 3.29 \mathrm{mmol})$ in $\mathrm{CH}_{2} \mathrm{Cl}_{2}$ $(10 \mathrm{~mL})$ was added tosyl chloride $(1.57 \mathrm{~g}, 8.24 \mathrm{mmol})$. The mixture was stirred vigorously and cold $40 \%$ aqueous $\mathrm{KOH}$ solution $(11 \mathrm{~mL})$ was added to it at $0{ }^{\circ} \mathrm{C}$. The resulting emulsion was stirred at $\mathrm{rt}$ for $23 \mathrm{~h}$ then water $(100 \mathrm{~mL})$ and $\mathrm{CH}_{2} \mathrm{Cl}_{2}(100 \mathrm{~mL})$ were added to it. The phases were shaken well and separated. The aqueous phase was extracted with $\mathrm{CH}_{2} \mathrm{Cl}_{2}(2 \times 50 \mathrm{~mL})$. The combined organic phase was dried over anhydrous $\mathrm{MgSO}_{4}$, filtered, and the solvent was evaporated. The crude product was purified by recrystallization from $\mathrm{CH}_{2} \mathrm{Cl}_{2}-\mathrm{MeOH}$ mixture to give ditosylate 18 (1.89 g, $94 \%)$ as white crystals. Mp: 129 $130{ }^{\circ} \mathrm{C}\left(\mathrm{CH}_{2} \mathrm{Cl}_{2}-\mathrm{MeOH}\right) ; R_{\mathrm{f}}: 0.22$ (silica gel TLC, EtOAchexane 1:3); IR (KBr) $v_{\text {max }} 3080,3072,3042,3022,2981$, 2957, 2944, 2921, 2875, 2794, 1598, 1583, 1502, 1449, $1403,1372,1355,1251,1178,1020,947,925,815,782,754$, $664,571,552 \mathrm{~cm}^{-1}$; ${ }^{1} \mathrm{H}$ NMR (300 MHz, $\left.\mathrm{CDCl}_{3}\right) \delta 2.44$ (s, 6H), 3.13 (s, 3H), 3.94-4.08 (m, 8H), $6.73(\mathrm{~d}, J=8 \mathrm{~Hz}$, 2H), 6.84-6.96 (m, 6H), 7.30 (d, $J=7 \mathrm{~Hz}, 4 \mathrm{H}), 7.75$ (d, $J=7 \mathrm{~Hz}, 4 \mathrm{H}) ;{ }^{13} \mathrm{C} \mathrm{NMR}\left(75.5 \mathrm{MHz}, \mathrm{CDCl}_{3}\right) \delta 21.65,39.76$, $66.29,68.35,115.06,121.75,122.20,123.05,127.95,129.85$, 132.99, 140.74, 144.85, 151.05; MS calcd for $\mathrm{C}_{31} \mathrm{H}_{33} \mathrm{NO}_{8} \mathrm{~S}_{2}$ : 611.2, found $(\mathrm{M}+\mathrm{H})^{+}$: 612.2; Anal. calcd for $\mathrm{C}_{31} \mathrm{H}_{33} \mathrm{NO}_{8} \mathrm{~S}_{2}$ : C 60.87, H 5.44, N 2.29, found: C 60.53, H 5.56, N 2.10.

\subsection{2-(Methoxymethoxy)ethyl 4-methylbenzenesulfonate (20)}

To a vigorously stirred mixture of ethylene glycol derivative 19 [52] (1.63 g, $15.4 \mathrm{mmol})$ containing a MOM protecting group, $\mathrm{CH}_{2} \mathrm{Cl}_{2}(12 \mathrm{~mL})$, and cold $40 \%$ aqueous $\mathrm{KOH}$ solution $(17 \mathrm{~mL})$ a solution of tosyl chloride (3.81 g, $20.0 \mathrm{mmol})$ in $\mathrm{CH}_{2} \mathrm{Cl}_{2}(12 \mathrm{~mL})$ was added dropwise at $0{ }^{\circ} \mathrm{C}$. The resulting reaction mixture was stirred at $\mathrm{rt}$ for 1 day then washed into a separatory funnel with $\mathrm{CH}_{2} \mathrm{Cl}_{2}(175 \mathrm{~mL})$ and water $(75 \mathrm{~mL})$. The resulting mixture was shaken well and separated. The aqueous phase was extracted with $\mathrm{CH}_{2} \mathrm{Cl}_{2}(3 \times 150 \mathrm{~mL})$. The combined organic phase was dried over anhydrous $\mathrm{MgSO}_{4}$, filtered and evaporated. The crude product was purified by column chromatography on silica gel using EtOAc-hexane
1:6 mixture as an eluent to give tosylate $\mathbf{2 0}(3.65 \mathrm{~g}, 91 \%)$ as a colorless oil. $R_{\mathrm{f}}: 0.18$ (silica gel TLC, EtOAc-hexane $1: 2)$; IR (neat) $v_{\max } 2948,2888,2825,1598,1496,1451$, 1399, 1354, 1307, 1291, 1242, 1213, 1189, 1174, 1153, 1120, 1096, 1051, 1007, 913, 815, 773, 706, 691, 661, 575, 552, $501 \mathrm{~cm}^{-1} ;{ }^{1} \mathrm{H}$ NMR $\left(500 \mathrm{MHz}, \mathrm{CDCl}_{3}\right) \delta 2.46(\mathrm{~s}, 3 \mathrm{H})$, $3.32(\mathrm{~s}, 3 \mathrm{H}), 3.72(\mathrm{t}, J=5 \mathrm{~Hz}, 2 \mathrm{H}), 4.20(\mathrm{t}, J=5 \mathrm{~Hz}, 2 \mathrm{H})$, 4.57 (s, 2H), 7.36 (d, $J=8 \mathrm{~Hz}, 2 \mathrm{H}), 7.81$ (d, $J=8 \mathrm{~Hz}$, $2 \mathrm{H}) ;{ }^{13} \mathrm{C}$ NMR $\left(75.5 \mathrm{MHz}, \mathrm{CDCl}_{3}\right) \delta 21.62,55.31,65.09$, 69.18, 96.46, 127.94, 129.82, 133.03, 144.85; MS calcd for $\mathrm{C}_{11} \mathrm{H}_{16} \mathrm{O}_{5} \mathrm{~S}: 260.1$, found $\left(\mathrm{M}+\mathrm{NH}_{4}\right)^{+}: 278.1$; Anal. calcd for $\mathrm{C}_{11} \mathrm{H}_{16} \mathrm{O}_{5} \mathrm{~S}: \mathrm{C} 50.76, \mathrm{H} 6.20$, found: C 50.71, H 5.88 .

\subsection{General procedure for the synthesis of precursors $(R, R)$-21 and $(S, S)$-21 containing MOM protecting groups}

A suspension of $\mathrm{NaH}(510 \mathrm{mg}, 12.7 \mathrm{mmol}, 60 \%$ dispersion in mineral oil) was stirred vigorously in pure and dry THF $(2 \mathrm{~mL})$ under Ar for $5 \mathrm{~min}$. To this suspension was added slowly aminodiol $(R, R)-6$ or $(S, S)-6(1.00 \mathrm{~g}, 2.12 \mathrm{mmol})$ dissolved in pure and dry DMF $(5 \mathrm{~mL})$ at $-60{ }^{\circ} \mathrm{C}$. The resulting mixture was stirred at $\mathrm{rt}$ for $10 \mathrm{~min}$ and at $60^{\circ} \mathrm{C}$ for $2 \mathrm{~h}$. The mixture was cooled down to $0{ }^{\circ} \mathrm{C}$, and tosylate 20 (1.32 g, $5.07 \mathrm{mmol})$ dissolved in pure and dry DMF $(2 \mathrm{~mL})$ was added. After addition of the tosylate 20, the reaction mixture was allowed to warm up to rt, and it was stirred at this temperature overnight. The solvent was evaporated, and the residue was dissolved in a mixture of $\mathrm{Et}_{2} \mathrm{O}(120 \mathrm{~mL})$ and brine $(70 \mathrm{~mL})$. The phases were shaken well and separated. The aqueous phase was extracted with $\mathrm{Et}_{2} \mathrm{O}(3 \times 120 \mathrm{~mL})$. The combined organic phase was dried over anhydrous $\mathrm{MgSO}_{4}$, filtered and evaporated. The crude product was purified by column chromatography on silica gel using EtOAc-hexane 1:6 mixture as an eluent. Smaller amounts were purified for analytical studies by preparative TLC on silica gel using EtOAc-hexane 1:3 mixture as an eluent to give diacetal $(R, R)-\mathbf{2 1}$ or $(S, S)-\mathbf{2 1}$ as a yellow oil.

4.15.1 (R)-2-[2-(Methoxymethoxy)ethoxy]- $N-\{(R)-2-[2-$ (methoxymethoxy)ethoxy]-2-phenylethyl\}-2-phenyl- $N$ (pyren-1-ylmethyl)ethan-1-amine [(R,R)-21]

Yield: $920 \mathrm{mg}, 67$ \%; $R_{\mathrm{f}}: 0.46$ (silica gel TLC, EtOAc-hexane 1:2); $[\alpha]_{\mathrm{D}}^{25}-9.2$ ( $c=1.00$ in acetone); IR (neat) $v_{\max } 3080$, 3049, 3029, 2929, 2879, 2820, 1602, 1587, 1492, 1451, 1346, 
1311, 1244, 1213, 1152, 1103, 1038, 917, 845, 818, 756, 701, $644,615 \mathrm{~cm}^{-1}$; ${ }^{1} \mathrm{H}$ NMR (500 MHz, acetone- $\left.d_{6}\right) \delta 2.90-2.96$ (m, 2H), 3.06-3.13 (m, 2H), 3.21 (s, 6H), 3.40-3.52 (m, 4H), 3.57-3.65 $(\mathrm{m}, 4 \mathrm{H})$, the benzylic type protons give an AB quartet: $\delta_{\mathrm{A}} 4.52$ and $\delta_{\mathrm{B}} 4.76\left(J_{\mathrm{AB}}=13 \mathrm{~Hz}, 2 \mathrm{H}\right), 4.53(\mathrm{~s}, 4 \mathrm{H})$, 4.54-4.59 (m, 2H), 7.13-7.24 (m, 10H), 8.02 (t, $J=8 \mathrm{~Hz}$, $1 \mathrm{H}), 8.07-8.14(\mathrm{~m}, 4 \mathrm{H}), 8.17$ (d, $J=8 \mathrm{~Hz}, 1 \mathrm{H}), 8.21-8.26$ $(\mathrm{m}, 2 \mathrm{H}), 8.62$ (d, $J=9 \mathrm{~Hz}, 1 \mathrm{H}) ;{ }^{13} \mathrm{C}$ NMR $(125 \mathrm{MHz}$, acetone- $\left.d_{6}\right) \delta 54.21,58.50,62.15,66.83,68.20,81.70,96.18$, 124.38, 124.64, 124.78, 124.82, 124.93 (very high, probably two ${ }^{13} \mathrm{C}$ signals together), 125.93, 126.76, 126.79, 126.89, 127.23 , 127.52, 128.09, 128.48, 129.95, 130.66, 131.10, 131.40, 134.04, 141.66; MS calcd for $\mathrm{C}_{41} \mathrm{H}_{45} \mathrm{NO}_{6}: 647.3$, found $(\mathrm{M}+\mathrm{H})^{+}: 648.3$; Anal. calcd for $\mathrm{C}_{41} \mathrm{H}_{45} \mathrm{NO}_{6}$ : C 76.02, H 7.00, N 2.16, found: C 75.91, H 7.12, N 2.17.

\subsection{2 (S)-2-[2-(Methoxymethoxy)ethoxy]- $N$ - $\{(S)-2-$} [2-(methoxymethoxy)ethoxy]-2-phenylethyl\}-2-phenyl$N$-(pyren-1-ylmethyl)ethan-1-amine [ $(S, S)-21]$

Yield: $962 \mathrm{mg}, 70 \%$; $[\alpha]_{\mathrm{D}}^{25}+7.0$ ( $c=1.00$ in acetone). Spectral data and other physical properties of precursor $(S, S)$-21 were the same as those of precursor $(R, R)-\mathbf{2 1}$ reported above.

\subsection{General procedure for the synthesis of diols $(R, R)-22$ and $(S, S)-22$}

To a solution of bis(MOM)-protected diol $(R, R)-\mathbf{2 1}$ or $(S, S)-21(1.08 \mathrm{~g}, 1.67 \mathrm{mmol})$ in THF $(8 \mathrm{~mL})$ was added slowly $20 \%$ aqueous $\mathrm{HCl}$ solution $(50 \mathrm{~mL})$, and the resulting mixture was stirred at $55^{\circ} \mathrm{C}$ for $1 \mathrm{~h}$. The solvent was evaporated, and the residue was dissolved in a mixture of saturated aqueous $\mathrm{NaHCO}_{3}$ solution $(100 \mathrm{~mL})$ and EtOAc $(100 \mathrm{~mL})$. The phases were shaken well and separated. The aqueous phase was extracted with EtOAc $(2 \times 100 \mathrm{~mL})$. The combined organic phase was dried over anhydrous $\mathrm{MgSO}_{4}$, filtered and evaporated to give unprotected diol $(R, R)$-22 or $(S, S)-\mathbf{2 2}$ as white crystals.

\subsubsection{2,2'-\{[(1R,1'R)-[(Pyren-1-ylmethyl)azanediyl]} bis(1-phenylethane-2,1-diyl)]bis(oxy)\}bis(ethan-1-ol) [(R,R)-22]

Yield: $917 \mathrm{mg}, 98 \%$; mp: $42-43{ }^{\circ} \mathrm{C}$; $R_{\mathrm{f}}: 0.07$ (silica gel TLC, EtOAc-hexane $1: 2) ;[\alpha]_{\mathrm{D}}^{25}-48.6(c=1.00$ in acetone); IR $(\mathrm{KBr}) v_{\max } 3383(\mathrm{br}, \mathrm{OH}), 3083,3048,3032,2923,2854$, 1602, 1586, 1491, 1451, 1417, 1380, 1346, 1313, 1260, 1199, 1096, 1054, 1021, 964, 929, 888, 842, 817, 754, 699, 643, $615 \mathrm{~cm}^{-1} ;{ }^{1} \mathrm{H}$ NMR (500 MHz, acetone- $\left.d_{6}\right) \delta 2.82-2.88$ (m, 2H), 3.15-3.23 (m, 2H), 3.40-3.48 (m, 4H), 3.62-3.75 (m, 4H), 3.97 (br s, 2H, OH, disappears after shaking the solution with $\mathrm{D}_{2} \mathrm{O}$ ), the benzylic type protons give an $\mathrm{AB}$ quartet: $\delta_{\mathrm{A}} 4.60$ and $\delta_{\mathrm{B}} 4.64\left(J_{\mathrm{AB}}=13 \mathrm{~Hz}, 2 \mathrm{H}\right), 4.66-4.72$ (m, 2H), 7.18-7.30 (m, 10H), 8.06 (t, $J=8 \mathrm{~Hz}, 1 \mathrm{H}), 8.10-$ 8.17 (m, 4H), $8.20(\mathrm{~d}, J=8 \mathrm{~Hz}, 1 \mathrm{H}), 8.24-8.31$ (m, 2H), $8.66(\mathrm{~d}, J=9 \mathrm{~Hz}, 1 \mathrm{H}) ;{ }^{13} \mathrm{C} \mathrm{NMR}\left(125 \mathrm{MHz}\right.$, acetone- $\left.d_{6}\right)$ $\delta$ 58.41, 61.25, 62.30, 70.50, 80.82, 124.38, 124.61, 124.78 (high, probably two ${ }^{13} \mathrm{C}$ signals together), 124.86, 124.96, $125.94,126.75,126.91,126.95,127.27,127.49,128.12$, 128.62, 130.00, 130.70, 131.05, 131.37, 133.51, 141.62; MS calcd for $\mathrm{C}_{37} \mathrm{H}_{37} \mathrm{NO}_{4}$ : 559.3, found $(\mathrm{M}+\mathrm{H})^{+}$: 560.3; Anal. calcd for $\mathrm{C}_{37} \mathrm{H}_{37} \mathrm{NO}_{4}$ : C 79.40, H 6.66, N 2.50, found: C 79.09, H 6.54, N 2.28.

\subsubsection{2,2'-\{[(1S,1'S)-[(Pyren-1-ylmethyl)azanediyl]} bis(1-phenylethane-2,1-diyl)]bis(oxy)\}bis(ethan-1-ol) [(S,S)-22]

Yield: $912 \mathrm{mg}, 98 \%$; $[\alpha]_{\mathrm{D}}^{25}+50.4$ ( $c=1.00$ in acetone). Spectral data and other physical properties of diol $(S, S)$-22 were the same as those of diol $(R, R)-\mathbf{2 2}$ reported above.

\subsection{General procedure for the synthesis of ditosylates $(R, R)-23$ and $(S, S)-23$}

Diol $(R, R)$-22 or $(S, S)-22$ (866 mg, $1.55 \mathrm{mmol})$ was stirred vigorously in a mixture of $\mathrm{CH}_{2} \mathrm{Cl}_{2}(15 \mathrm{~mL})$ and cold $40 \%$ aqueous $\mathrm{KOH}$ solution $(20 \mathrm{~mL})$ at $0{ }^{\circ} \mathrm{C}$, and a solution of tosyl chloride ( $885 \mathrm{mg}, 4.63 \mathrm{mmol}$ ) in $\mathrm{CH}_{2} \mathrm{Cl}_{2}(5 \mathrm{~mL})$ was added dropwise to it. The resulting reaction mixture was stirred at $\mathrm{rt}$ for 1 day then washed into a separatory funnel with $\mathrm{CH}_{2} \mathrm{Cl}_{2}(100 \mathrm{~mL})$ and water $(80 \mathrm{~mL})$. The resulting mixture was shaken well and separated. The aqueous phase was extracted with $\mathrm{CH}_{2} \mathrm{Cl}_{2}(2 \times 100 \mathrm{~mL})$. The combined organic phase was dried over anhydrous $\mathrm{MgSO}_{4}$, filtered and evaporated. The crude product was purified by column chromatography on silica gel using EtOAc-hexane 1:4 mixture as an eluent to give ditosylate $(R, R)-\mathbf{2 3}$ or $(S, S)-\mathbf{2 3}$ as white crystals.

\subsection{1 \{[(1R,1'R)-[(Pyren-1-ylmethyl)azanediyl]bis(1- phenylethane-2,1-diyl)]bis(oxy)\}bis(ethane-2,1-diyl) bis(4-methylbenzenesulfonate) $[(\boldsymbol{R}, \boldsymbol{R})-23]$}

Yield: $577 \mathrm{mg}, 43 \%$; mp: $60-62{ }^{\circ} \mathrm{C}$; $R_{\mathrm{f}}: 0.48$ (silica gel TLC, EtOAc-hexane 1:2); $[\alpha]_{\mathrm{D}}^{25}-27.4(c=1.11$ in acetone); IR (KBr) $v_{\max } 3433$ (br, complexed $\left.\mathrm{H}_{2} \mathrm{O}\right), 3082$, 3051, 3032, 2952, 2922, 2874, 1597, 1494, 1454, 1357, 1189, 1176, 1120, 1097, 1033, 1012, 921, 852, 816, 760, 702, 680, 664, 
$554 \mathrm{~cm}^{-1} ;{ }^{1} \mathrm{H}$ NMR (500 MHz, $\left.\mathrm{CDCl}_{3}\right) \delta 1.67$ (br s, complexed $\left.\mathrm{H}_{2} \mathrm{O}, 2 \mathrm{H}\right), 2.26(\mathrm{~s}, 6 \mathrm{H}), 2.79-2.87(\mathrm{~m}, 2 \mathrm{H}), 2.95-$ $3.03(\mathrm{~m}, 2 \mathrm{H}), 3.36-3.43(\mathrm{~m}, 4 \mathrm{H}), 4.03-4.13$ (m, 4H), 4.23$4.29(\mathrm{~m}, 2 \mathrm{H})$, the benzylic type protons give an $\mathrm{AB}$ quartet: $\delta_{\mathrm{A}} 4.29$ and $\delta_{\mathrm{B}} 4.58\left(J_{\mathrm{AB}}=13 \mathrm{~Hz}, 2 \mathrm{H}\right), 6.94-7.01(\mathrm{~m}, 4 \mathrm{H})$, $7.10(\mathrm{~d}, J=8 \mathrm{~Hz}, 4 \mathrm{H}), 7.13-7.18$ (m, 6H), 7.65 (d, $J=8 \mathrm{~Hz}$, 4H), 7.89 (d, $J=8 \mathrm{~Hz}, 1 \mathrm{H}), 7.96$ (d, $J=9 \mathrm{~Hz}, 1 \mathrm{H}), 8.01$ (t, $J=8 \mathrm{~Hz}, 1 \mathrm{H}), 8.04-8.09$ (m, 3H), 8.15-8.20 (m, 2H), 8.37 (d, $J=9 \mathrm{~Hz}, 1 \mathrm{H}) ;{ }^{13} \mathrm{C} \mathrm{NMR}\left(125 \mathrm{MHz}, \mathrm{CDCl}_{3}\right) \delta 21.60$, 59.26, 62.57, 66.40, 69.46, 82.37, 124.45, 124.62, 124.86, $124.93,124.98,125.10,125.92,126.85,126.98,127.10$, $127.62,127.72,127.95,128.25,128.39,129.79,129.96$, 130.76, 131.07, 131.41, 133.07, 133.52, 140.47, 144.70; MS calcd for $\mathrm{C}_{51} \mathrm{H}_{49} \mathrm{NO}_{8} \mathrm{~S}_{2}: 867.3$, found $(\mathrm{M}+\mathrm{H})^{+}:$: 868.3; Anal. calcd for $\mathrm{C}_{51} \mathrm{H}_{49} \mathrm{NO}_{8} \mathrm{~S}_{2} \cdot \mathrm{H}_{2} \mathrm{O}: \mathrm{C} 69.13, \mathrm{H} 5.80, \mathrm{~N} 1.58$, found: C 68.89, H 6.08, N 1.56 .

\section{References}

[1] Späth, A., König, B. "Molecular recognition of organic ammonium ions in solution using synthetic receptors", Beilstein Journal of Organic Chemistry, 6(32), 2010.

https://doi.org/10.3762/bjoc.6.32

[2] Nunez, M. C., Garcia-Rubino, M. E., Conejo-Garcia, A., CruzLopez, O., Kimatrai, M., Gallo, M. A., Espinosa, A., Campos, J. M. "Homochiral Drugs: A Demanding Tendency of the Pharmaceutical Industry", Current Medicinal Chemistry, 16(16), pp. 2064-2074, 2009.

https://doi.org/10.2174/092986709788682173

[3] Lakowicz, J. R. "Principles of Fluorescence Spectroscopy", 3rd ed., Springer, Boston, MA, USA, 2006.

https://doi.org/10.1007/978-0-387-46312-4

[4] Pu, L. "Fluorescence of Organic Molecules in Chiral Recognition", Chemical Reviews, 104(3), pp. 1687-1716, 2004.

https://doi.org/10.1021/cr030052h

[5] Accetta, A., Corradini, R., Marchelli, R. "Enantioselective Sensing by Luminescence", In: Prodi, L., Montalti, M., Zaccheroni, N. (eds.) Luminescence Applied in Sensor Science, Springer, Berlin, Heidelberg, Germany, 2010, pp. 175-216.

https://doi.org/10.1007/128_2010_95

[6] Pu, L. "Enantioselective Fluorescent Sensors: A Tale of BINOL", Accounts of Chemical Research, 45(2), pp. 150-163, 2011. https://doi.org/10.1021/ar200048d

[7] Zhang, X., Yin, J., Yoon, J. "Recent Advances in Development of Chiral Fluorescent and Colorimetric Sensors", Chemical Reviews, 114(9), pp. 4918-4959, 2014.

https://doi.org/10.1021/cr400568b

[8] Wang, J., Liu, H.-B., Tong, Z., Ha, C.-S. "Fluorescent/luminescent detection of natural amino acids by organometallic systems", Coordination Chemistry Reviews, 303, pp. 139-184, 2015. https://doi.org/10.1016/j.ccr.2015.05.008

\subsection{2 \{[(1S,1'S)-[(Pyren-1-ylmethyl)azanediyl]bis(1- phenylethane-2,1-diyl)]bis(oxy)\}bis(ethane-2,1-diyl) bis(4-methylbenzenesulfonate) [(S,S)-23]}

Yield: $698 \mathrm{mg}, 52 \%$; $[\alpha]_{\mathrm{D}}^{25}+24.1(c=1.00$ in acetone $)$. Spectral data and other physical properties of ditosylate $(S, S)$-23 were the same as those of ditosylate $(R, R)-\mathbf{2 3}$ reported above.

\section{Acknowledgements}

Financial supports of the National Research, Development and Innovation Office - NKFIH (earlier OTKA) (NKFIH No. K 112289, K 128473, and NVKP 16-1-2016-0043) and the New Széchenyi Development Plan (TÁMOP4.2.1/B-09/1/KMR-2010-0002) are gratefully acknowledged. The authors thank Dr. György Tibor Balogh, Dr. Judit Müller, and Zsófia Petrik for chiral HPLC measurements.

[9] You, L., Zha, D., Anslyn, E. V. "Recent Advances in Supramolecular Analytical Chemistry Using Optical Sensing", Chemical Reviews, 115(15), pp. 7840-7892, 2015. https://doi.org/10.1021/cr5005524

[10] Yu, S., Pu, L. "Recent progress on using BINOLs in enantioselective molecular recognition", Tetrahedron, 71(5), pp. 745-772, 2015. https://doi.org/10.1016/j.tet.2014.11.007

[11] Wen, K., Yu, S., Huang, Z., Chen, L., Xiao, M., Yu, X., Pu, L. "Rational Design of a Fluorescent Sensor to Simultaneously Determine Both the Enantiomeric Composition and the Concentration of Chiral Functional Amines", Journal of the American Chemical Society, 137(13), pp. 4517-4524, 2015. https://doi.org/10.1021/jacs.5b01049

[12] Pu, L. "Simultaneous Determination of Concentration and Enantiomeric Composition in Fluorescent Sensing", Accounts of Chemical Research, 50(4), pp. 1032-1040, 2017. https://doi.org/10.1021/acs.accounts.7b00036

[13] Zeng, C., Zhang, X., Pu, L. "Enantioselective Fluorescent Imaging of Free Amino Acids in Living Cells", Chemistry, A European Journal, 23(10), pp. 2432-2438, 2017. https://doi.org/10.1002/chem.201605028

[14] Wang, C., Zeng, C., Zhang, X., Pu, L. "Enantioselective Fluorescent Recognition of Amino Acids by Amide Formation: An Unusual Concentration Effect", The Journal of Organic Chemistry, 82(23), pp. 12669-12673, 2017. https://doi.org/10.1021/acs.joc.7b02456

[15] Zhang, X., Yu, Q., Lu, W., Chen, S., Dai, Z. "Synthesis of new chiral fluorescent sensors and their applications in enantioselective discrimination", Tetrahedron Letters, 58(41), pp. 3924-3927, 2017. https://doi.org/10.1016/j.tetlet.2017.08.077 
[16] Noguchi, T., Roy, B., Yoshihara, D., Sakamoto, J., Yamamoto, T., Shinkai, S. "A Chiral Recognition System Orchestrated by SelfAssembly: Molecular Chirality, Self-Assembly Morphology, and Flourescence Response", Angewandte Chemie International Edition, 56(41), pp. 12518-12522, 2017. https://doi.org/10.1002/anie.201706142

[17] Zhang, X., Yu, Q., Chen, S., Dai, Z. "A photo-stable fluorescent chiral thiourea probe for enantioselective discrimination of chiral guests", New Journal of Chemistry, 42(6), pp. 4045-4051, 2018. https://doi.org/10.1039/C8NJ00374B

[18] Muralidharan, V. P., Sathiyanarayanan, K. I. "NaphthalimideBased Chiral Fluorescence Sensor Employing (S)-BINOL Unit for Highly Enantioselective Recognition of $\alpha$-Amino Alcohols with Opposite Chiral Selectivity", ChemistrySelect, 3(11), pp. 3111-3117, 2018. https://doi.org/10.1002/slct.201703101

[19] Zhao, F., Du, Y., Tian, J., Shi, D., Wang, Y., Hu, L., Yu, S., Yu, $\mathrm{X}$., Pu, L. "Enantioselective Fluorescent Recognition of Amino Acids in Aqueous Solution by Using a Chiral Aldehyde Probe", European Journal of Organic Chemistry, 2018(16), pp. 1891-1895, 2018.

https://doi.org/10.1002/ejoc.201701773

[20] Tundo, P., Fendler, J. H. "Photophysical investigations of chiral recognition in crown ethers", Journal of the American Chemical Society, 102(5), pp. 1760-1762, 1980. https://doi.org/10.1021/ja00525a067

[21] Móczár, I., Huszthy, P. "Optically active crown ether-based fluorescent sensor molecules: A mini-review", Chirality, 31(2), pp. 97-109, 2019.

https://doi.org/10.1002/chir.23031

[22] Pál, D., Móczár, I., Szemenyei, B., Marczona, D., Kocsis, I., Prikler, G., Vezse, P., Baranyai, P., Huszthy, P. "Pyridino-18crown-6 ether type chemosensors containing a benzothiazole fluorophore unit: Synthesis and enantiomeric recognition studies", Tetrahedron, 75(20), pp. 2900-2909, 2019. https://doi.org/10.1016/j.tet.2019.04.024

[23] Kertész, J., Móczár, I., Kormos, A., Baranyai, P., Kubinyi, M., Tóth, K., Huszthy, P. "Synthesis and enantiomeric recognition studies of dialkyl-substituted 18-crown-6 ethers containing an acridine fluorophore unit", Tetrahedron: Asymmetry, 22(6), pp. 684-689, 2011. https://doi.org/10.1016/j.tetasy.2011.03.011

[24] Rapi, Zs., Bakó, P., Keglevich, Gy., Baranyai, P., Kubinyi, M., Varga, O. "Synthesis and recognition properties of $\alpha$-D-glucosebased fluorescent crown ethers incorporating an acridine unit", Journal of Inclusion Phenomena and Macrocyclic Chemistry, 80(3-4), pp. 253-261, 2014. https://doi.org/10.1007/s10847-014-0384-8

[25] Szemenyei, B., Móczár, I., Pál, D., Kocsis, I., Baranyai, P., Huszthy, P. "Synthesis and Enantiomeric Recognition Studies of Optically Active Pyridino-Crown Ethers Containing an Anthracene Fluorophore Unit", Chirality, 28(7), pp. 562-568, 2016. https://doi.org/10.1002/chir.22614
[26] Németh, T., Tóth, T., Balogh, Gy. T., Huszthy, P. "Synthesis and Fluorescence Spectroscopic Studies of Novel 9-phenylacridino-18-crown-6 Ether Type Sensor Molecules", Periodica Polytechnica Chemical Engineering, 61(4), pp. 249-257, 2017. https://doi.org/10.3311/PPch.11277

[27] de Silva, A. P., Gunaratne, H. Q. N., Gunnlaugsson, T., Huxley, A. J. M., McCoy, C. P., Rademacher, J. T., Rice, T. E. "Signaling Recognition Events with Fluorescent Sensors and Switches", Chemical Reviews, 97(5), pp. 1515-1566, 1997. https://oi.org/10.1021/cr960386p

[28] Valeur, B., Leray, I. "Design principles of fluorescent molecular sensors for cation recognition", Coordination Chemistry Reviews, 205(1), pp. 3-40, 2000. https://doi.org/10.1016/S0010-8545(00)00246-0

[29] de Silva, A. P., McClean, G. D., Moody, T. S., Weir, S. M. "Luminescent Sensors and Switches", In: Nalwa, H. S. (ed.) Handbook of Photochemistry and Photobiology, American Scientific Publishers, Stevenson Ranch, CA, USA, 2003, pp. 217-270.

[30] Montalti, M., Prodi, L., Zaccheroni, N. "Luminescent Chemosensors for Metal Ions", In: Nalwa, H. S. (ed.) Handbook of Photochemistry and Photobiology, American Scientific Publishers, Stevenson Ranch, CA, USA, 2003, pp. 271-317.

[31] Kubo, K. "PET Sensors", In: Geddes, C. D., Lakowicz, J. R. (eds.) Topics in Fluorescence Spectroscopy, Vol. 9, Springer, Boston, MA, USA, 2005, pp. 219-247. https://doi.org/10.1007/0-387-23335-0_6

[32] Callan, J. F., de Silva, A. P., Magri, D. C. "Luminescent sensors and switches in the early 21 st century", Tetrahedron, 61(36), pp. 8551-8588, 2005. https://doi.org/10.1016/j.tet.2005.05.043

[33] de Silva, A. P., Magri, D. C. "Optical Sensing and Switching with Designed Molecules", Chimia, 59(5), pp. 218-221, 2005. https://doi.org/10.2533/000942905777676579

[34] de Silva, A. P., Vance, T. P., West, M. E. S., Wright, G. D. "Bright molecules with sense, logic, numeracy and utility", Organic and Biomolecular Chemistry, 6(14), pp. 2468-2480, 2008. https://doi.org/10.1039/b802963f

[35] de Silva, A. P., Moody, T. S., Wright, G. D. "Fluorescent PET (Photoinduced Electron Transfer) sensors as potent analytical tools", Analyst, 134(12), pp. 2385-2393, 2009. https://doi.org/10.1039/b912527m

[36] Demchenko, A. P. "Introduction to Fluorescence Sensing", 2nd ed., Springer, Cham, Switzerland, 2015. https://doi.org/10.1007/978-3-319-20780-3

[37] Daly, B., Ling, J., de Silva, A. P. "Current developments in fluorescent PET (photoinduced electron transfer) sensors and switches", Chemical Society Reviews, 44(13), pp. 4203-4211, 2015. https://doi.org/10.1039/C4CS00334A

[38] Kubo, K., Kato, N., Sakurai, T. "Synthesis and Complexation Behavior of Diaza-18-crown-6 Carrying Two Pyrenylmethyl Groups", Bulletin of the Chemical Society of Japan, 70(12), pp. 3041-3046, 1997. https://doi.org/10.1246/bcsj.70.3041 
[39] Ji, H.-F., Dabestani, R., Brownxy, G. M., Hettich, R. L. "Spacer Length Effect on the Photoinduced Electron Transfer Fluorescent Probe for Alkali Metal Ions", Photochemistry and Photobiology, 69(5), pp. 513-516, 1999. https://doi.org/10.1111/j.1751-1097.1999.tb03321.x

[40] Ocak, Ü., Ocak, M., Başoğlu, A., Parlayan, S., Alp, H., Kantekin, H. "Complexation of metal ions with the novel diazadithia crown ethers carrying two pyrene pendants in acetonitrile-tetrahydrofuran", Journal of Inclusion Phenomena and Macrocyclic Chemistry, 67(1-2), pp. 19-27, 2010. https://doi.org/10.1007/s10847-009-9663-1

[41] Ocak, Ü., Ocak, M., Parlayan, S., Başoğlu, A., Çağlar, Y., Bahadır,Z. "Azathia crown ethers carrying pyrene pendant as receptor molecules for metal sensor systems", Journal of Luminescence, 131(4), pp. 808-814, 2011.

https://doi.org/10.1016/j.jlumin.2010.12.008

[42] Nakatsuji, Y., Nakamura, M., Oka, T., Muraoka, M. "Selective Fluorometric Sensing of Calcium Cation by C-Pivot Lariat Monoaza-crown Ether with Two Pyrene Moieties", Chemistry Letters, 40(11), pp. 1226-1228, 2011.

https://doi.org/10.1246/cl.2011.1226

[43] Kim, K. S., Jun, E. J., Kim, S. K., Choi, H. J., Yoo, J., Lee, C.-H., Hyun, M. H., Yoon, J. "Fluorescent studies of two new binaphthyl-azacrown-anthracene fluorophores with metal ions and chiral guests: dual fluorescent detection via binaphthyl and anthracene groups", Tetrahedron Letters, 48(14), pp. 2481-2484, 2007. https://doi.org/10.1016/j.tetlet.2007.02.028

[44] Móczár, I., Huszthy, P., Mezei, A., Kádár, M., Nyitrai, J., Tóth, K. "Synthesis and optical characterization of novel azacrown ethers containing an acridinone or an $N$-methylacridinone unit as potential fluorescent chemosensors", Tetrahedron, 66(1), pp. 350-358, 2010. https://doi.org/10.1016/j.tet.2009.10.076

[45] Yuan, Y., Yan, X.-S., Li, X.-R., Cao, J.-L., Li, Z., Jiang, Y.-B. "Folded short azapeptide for conformation switching-based fluorescence sensing", Chemical Communications, 53(98), pp. $13137-$ 13140, 2017. https://doi.org/10.1039/C7CC06915D

[46] Ouchi, M., Inoue, Y., Liu, Y., Nagamune, S., Nakamura, S., Wada, K., Hakushi, T. "Convenient and Efficient Tosylation of Oligoethylene Glycols and the Related Alcohols in Tetrahydrofuran-Water in the Presence of Sodium Hydroxide", Bulletin of the Chemical Society of Japan, 63(4), pp. 1260-1262, 1990.

https://doi.org/10.1246/bcsj.63.1260
[47] Huang, X., Buchwald, S. L. "New Ammonia Equivalents for the Pd-Catalyzed Amination of Aryl Halides", Organic Letters, 3(21), pp. 3417-3419, 2001. https://doi.org/10.1021/o10166808

[48] Farfán, N., Joseph-Nathan, P., Chiquete, L. M., Contreras, R. "Syntheses and structures of two new dibenzobicyclic phenylboronates", Journal of Organometallic Chemistry, 348(2), pp. 149-156, 1988. https://doi.org/10.1016/0022-328X(88)80390-5

[49] Mancilla, T., Castillo, D., Carrillo, L., Farfán, N. "Diorganotin(IV) Compounds Derived from $N$-methyl-2,2'-diphenolamine and 2,2'Diphenolamine", Heteroatom Chemistry, 10(2), pp. 133-139, 1999. https://doi.org/10.1002/(SICI)1098-1071(1999)10:2<133::AID-HC6 $>3.0 . \mathrm{CO} ; 2-\mathrm{F}$

[50] Lakatos, Sz., Fetter, J., Bertha, F., Huszthy, P., Tóth, T., Farkas, V., Orosz, Gy., Hollósi, M. "Preparation of a new chiral acridino18-crown-6 ether-based stationary phase for enantioseparation of racemic protonated primary aralkyl amines", Tetrahedron, 64(6), pp. 1012-1022, 2008.

https://doi.org/10.1016/j.tet.2007.09.056

[51] Butler, C. L., Renfrew, A. G., Clapp, M. "The Preparation of Benzyloxyalkyl $p$-Toluenesulfonates", Journal of the American Chemical Society, 60(6), pp. 1472-1473, 1938. https://doi.org/10.1021/ja01273a058

[52] Shostakovskii, M. F., Kuznetsov, N. V., Zaretskaya, Y. B. "New method of synthesis of unsymmetrical acetals", Russian Chemical Bulletin, 12(5), pp. 830-831, 1963. https://doi.org/10.1007/BF01134734

[53] Jain, A., Purohit, C. S., Verma, S., Sankararamakrishnan, R. "Close Contacts between Carbonyl Oxygen Atoms and Aromatic Centers in Protein Structures: $\pi \cdots \pi$ or Lone-Pair $\cdots \pi$ Interactions?", The Journal of Physical Chemistry B, 111(30), pp. 8680-8683, 2007. https://doi.org/10.1021/jp0727421

[54] Mooibroek, T. J., Gamez, P., Reedijk, J. "Lone pair- $\pi$ interactions: a new supramolecular bond?", CrystEngComm, 10(11), pp. 1501-1515, 2008. https://doi.org/10.1039/b812026a

[55] Riddick, J. A., Bunger, W. B., Sakano, T. K. "Organic Solvents: Physical Properties and Methods of Purification", 4th ed., WileyInterscience, New York, NY, USA, 1986.

[56] Köntös, Z., Huszthy, P., Bradshaw, J. S., Izatt, R. M. "Enantioseparation of racemic organic ammonium perchlorates by a silica gel bound optically active di-tert-butylpiridino-18-crown-6 ligand", Tetrahedron: Asymmetry, 10(11), pp. 2087-2099, 1999. https:/doi.org/10.1016/S0957-4166(99)00163-9 